\title{
Stem cells and chronic wound healing: state of the art
}

This article was published in the following Dove Press journal:

Chronic Wound Care Management and Research

2 March 2016

Number of times this article has been viewed

\section{Tripp Leavitt}

Michael S Hu

Clement D Marshall

Leandra A Barnes

Michael T Longaker

H Peter Lorenz

Hagey Laboratory for Pediatric Regenerative Medicine, Division of Plastic Surgery, Department of Surgery, Stanford University School of Medicine, Stanford, CA, USA
Correspondence: $\mathrm{H}$ Peter Lorenz Hagey Laboratory for Pediatric

Regenerative Medicine, Division of Plastic Surgery, Department of Surgery, Stanford University School of Medicine, 257

Campus Drive, MC 5I48, Stanford, CA 94305, USA

Tel +l 6507254297

Fax +l 6507256605

Email plorenz@stanford.edu

\begin{abstract}
Currently available treatments for chronic wounds are inadequate. A clearly effective therapy does not exist, and treatment is often supportive. This is largely because the cellular and molecular processes underlying failure of wound repair are still poorly understood. With an increase in comorbidities, such as diabetes and vascular disease, as well as an aging population, the incidence of these intractable wounds is expected to rise. As such, chronic wounds, which are already costly, are rapidly growing as a tremendous burden to the health-care system. Stem cells have garnered much interest as a therapy for chronic wounds due to their inherent ability to differentiate into multiple lineages and promote regeneration. Herein, we discuss the types of stem cells used for chronic wound therapy, as well as the proposed means by which they do so. In particular, we highlight mesenchymal stem cells (including adipose-derived stem cells), endothelial progenitor cells, and induced pluripotent stem cells. We include the results of recent in vitro and in vivo studies in both animal models and human clinical trials. Finally, we discuss the current studies to improve stem cell therapies and the limitations of stem cell-based therapeutics. Stem cells promise improved therapies for healing chronic wounds, but further studies that are well-designed with standardized protocols are necessary for fruition.
\end{abstract}

Keywords: stem cells, chronic wounds, cell therapy, wound healing

\section{Introduction}

Chronic wounds represent a significant burden both financially and in terms of lost quality of life, affecting both individual patients and the health-care system as a whole. In North America alone, management of complex wounds, which include chronic wounds, pressure ulcers, and nonhealing surgical wounds, carries an annual price tag of US\$10 billion. Worldwide, the global wound care market is projected to surpass US\$22 billion per year by $2020 .{ }^{1}$ Whereas acute wounds are expected to eventually heal, chronic wounds are defined by a physiologically impaired healing response. Current wound management strategies remain unable to adequately treat chronic wounds, resulting in a vigorous pursuit of novel therapies, including those utilizing stem cells. The inherent regenerative capabilities of stem cells make them ideal targets for addressing the unmet clinical needs associated with chronic wounds, as well as expanding our understanding of the wound healing process. Though numerous clinical trials have measured the effects of stem cells in wound healing, most have been in the context of treating a more systemic illness such as critical limb ischemia (CLI); wound healing is instead often relegated to secondary outcome measures, making analysis of their clinical efficacy more difficult. This review will cover the clinically relevant sources of stem cells for chronic wound therapy, the means by which they modulate 
wound healing, and the results of recent in vitro and in vivo studies conducted in animals and humans. Both published and ongoing clinical trials will be discussed, in addition to where the field is headed. While this review focuses specifically on stem cells as they relate to chronic wound therapy, the reader is directed to the review by $\mathrm{Li}$ and $\mathrm{Fu}^{2}$ for a more in-depth discussion of stem cell mechanisms involved in physiological wound healing.

\section{Stem cell sources for regenerative medicine}

Stem cells are defined by their ability to self-renew and differentiate into multiple cell types. They are categorized as either multipotent or pluripotent based on the variety of cell lineages to which they may give rise. Multipotent cells are equivalent to adult stem cells, with the ability to differentiate into several different lineages. Pluripotent cells are embryonic stem cells (ESCs), with an even greater capacity for differentiation, able to form all of the functional cell types of an organism. Various stem cell populations have been the subjects of significant research efforts. The most clinically relevant stem cell populations include mesenchymal stem cells (MSCs), endothelial progenitor cells (EPCs), and induced pluripotent stem cells (iPSCs).

\section{Mesenchymal stem cells}

Under suitable conditions, MSCs have the ability to differentiate into bone, fat, cartilage, and muscle. Their ability to adhere to polystyrene tissue culture plastic remains a crude but effective means of isolating what is now understood to be a very heterogeneous population of progenitor cells. In addition to the aforementioned characteristics, the International Society for Cell Therapy has included cell surface expression in its guidelines for defining MSCs: CD73+, CD90

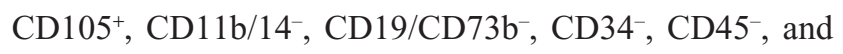
HLA-DR ${ }^{-3} \mathrm{CD}^{3} 71^{+}$has also been described as the most specific marker for bone marrow-derived mesenchymal stem cells (BM-MSCs) and adipose-derived stem cells (ASCs). ${ }^{4}$ However, consensus has yet to be reached with regard to their antigen expression profile. ${ }^{5}$ The inconstant nature of surface marker expression as these cells are removed from their native environment and expanded ex vivo merely worsens the surrounding controversy. ${ }^{6}$ Lack of standardization can thereby impede our ability to draw comparisons across studies. Despite these shortcomings, MSCs are understood to play a significant role in coordinating the wound healing response as it advances through phases of inflammation, proliferation, and remodeling. ${ }^{7}$ In addition to their capacity for self-renewal, MSCs have immunomodulatory effects at the local environments into which they are transplanted, ${ }^{8,9}$ supporting native cells via various paracrine mechanisms that promote cell survival, migration, and proliferation. ${ }^{10,11}$ This regenerative potential has garnered significant interest for applying MSCs in clinical interventions.

Within the larger group of cells termed MSCs, there are several described subpopulations, differentiated largely by their tissue of origin, but also in terms of sometimescontroversial differences in phenotype. MSCs reside in all mesenchymal tissues, a few of which are more practical for clinical purposes. BM-MSCs are one of the most studied populations. However, harvest of these cells necessitates painful bone marrow aspiration. This, in addition to the scarcity of BM-MSCs (1 in 10,000 mononuclear bone marrow cells $)^{12}$ has shifted favor toward the more accessible and abundant ASCs. With regards to cell-surface expression, the International Fat Applied Technology Society together with the International Society for Cell Therapy distinguish ASCs from MSCs by their positivity for CD36 and negativity for CD106 in culture. ${ }^{13}$ ASCs are generally harvested as part of lipoaspirate within the stromal vascular fraction (SVF), which itself has been used for regenerative wound therapy. ${ }^{14}$ The SVF contains a diverse population of cells, including endothelial, hematopoietic, and pericytic lineages, as well as MSCs. ASCs are believed to account for up to 3\% of total cells within isolated SVF, which is orders of magnitude higher than the corresponding proportion of MSCs in bone marrow. ${ }^{15}$

The relative dearth of MSCs in bone marrow aspirate has also led to the utilization of bone marrow mononuclear cells (BMMNCs) in clinical studies, which demonstrate their potential for accelerating wound healing. BMMNCs are also a heterogeneous group, thought to contain EPCs and MSCs in addition to an array of growth factors and cytokines, together promoting angiogenesis. ${ }^{16,17}$ Amniotic fluid, placental tissue, and umbilical cord (including Wharton's jelly and cord blood) are further sources of MSCs. Peripheral blood is also considered by some to be a source of MSCs following mobilization by granulocyte-colony stimulating factor (G-CSF) injection, though these mobilized cells would generally be classified as BMMNCs or peripheral blood mononuclear cells (PBMNCs). Recently, Li et al ${ }^{18}$ described a coculture system that routinely produces MSCs from peripheral blood without mobilization. Despite sharing the MSC moniker, populations from varying sources differ in terms of cell surface markers and differentiation efficiency, though they maintain their overall multipotent characteristics. 
While research has often focused on addressing the issues associated with a heterogeneous and poorly characterized cell population, the improved wound healing associated with MSC administration may in fact depend, at least in part, on multiple cell types working in concert. Rodriguez-Menocal et $\mathrm{al}^{19}$ demonstrated that whole bone marrow is more effective at stimulating angiogenesis relative to cultured bone marrow cells or MSCs, resulting in faster wound healing. A clinical study comparing BMMNCs to MSCs corroborated these findings in patients with chronic wounds. ${ }^{20}$ Similarly, BMMNCs demonstrate superior osteogenic and angiogenic differentiation potential compared with isolated CD34 cells. ${ }^{21}$ Administering heterogeneous groups of stem cells may allow for communication between different cell types, facilitating improved tissue regeneration, as is seen with coculture of MSCs together with EPCs. ${ }^{22}$

Applied to chronic wound therapies, both $\mathrm{MSCs}^{23,24}$ and $\mathrm{ASCs}^{25}$ have demonstrated an ability to improve wound healing in experimental diabetic models. Findings from in vitro experiments have elucidated a number of ways that BM-MSCs promote tissue regeneration, including production of growth factors, cytokines, collagens, and matrix metalloproteinases. ${ }^{26,27}$ Their direct interactions with other cells, such as keratinocytes, also accelerate wound healing. ${ }^{28}$ Despite their ability to differentiate into various cell types, the mechanism of action of MSCs is largely paracrine in nature. ${ }^{29}$ For example, ASC-conditioned media can stimulate the migration of vascular endothelial cells, fibroblasts, and keratinocytes, suggesting that the secretome can promote wound healing even in the absence of the cells themselves. ${ }^{30}$

\section{Endothelial progenitor cells}

Recruited from the bone marrow, EPCs circulate in the blood expressing hematopoietic and endothelial surface markers, localizing to sites of tissue injury and ischemia. ${ }^{31}$ At the wound bed they contribute to vasculogenesis, the process by which new vessels are formed from circulating progenitor cells. Like MSCs and ASCs, EPCs represent another heterogeneous population, with variations in classification that impede standardization of their clinical applications. The definition of EPCs overlaps with PBMNCs and BMMNCs (Figure 1), which may lead to confusion. In terms of clinical applications, EPCs are harvested from the peripheral blood (except Wettstein et $\mathrm{al}^{32}$ who harvested from bone marrow), often following G-CSF mobilization from the bone marrow, and are commonly enriched for $\mathrm{CD} 34$ positivity. The angiogenic potential of these cells has made them promising targets for treating chronic wounds with underlying ischemic pathologies.

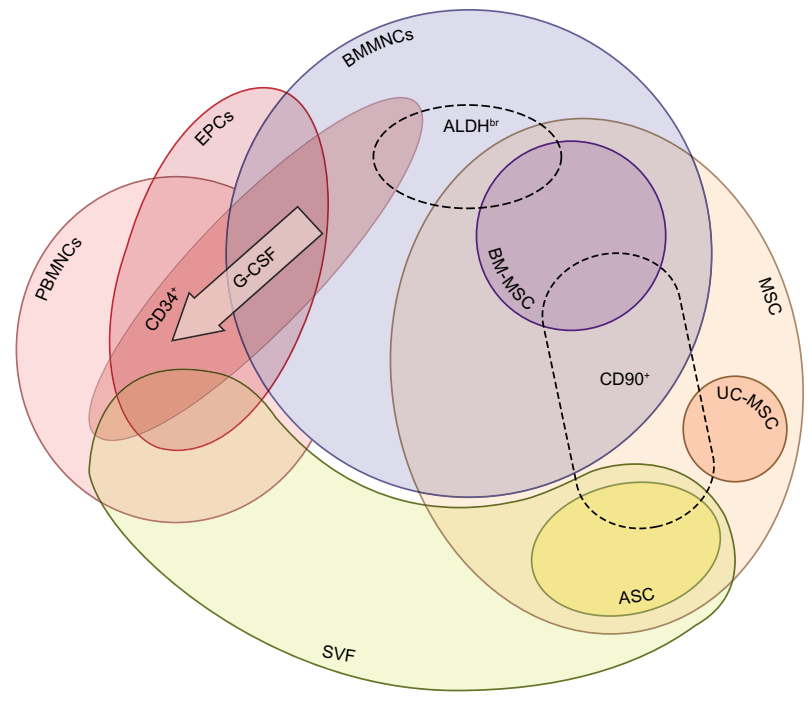

Figure I Stem cell populations administered in clinical trials.

Note: Dashed lines represent more ambiguously characterized populations. Abbreviations: $\mathrm{ALDH}^{\mathrm{br}}$, aldehyde dehydrogenase bright cell; EPC, endothelial progenitor cell; ASC, adipose-derived stem cell; BMMNC, bone-marrow mononuclear cell; BM-MSC, bone-marrow mesenchymal stem cell; SVF, stromal vascular fraction; PBMNC, peripheral blood mononuclear cell; G-CSF, granulocytecolony stimulating factor; UC-MSC, umbilical cord mesenchymal stem cell.

\section{Induced pluripotent stem cells}

In the search for regenerative cell therapies, ESCs provide an excellent early possibility given their pluripotent nature. However, ethical concerns regarding embryological tissue usage have limited their applications. Furthermore, when used in adults, these cells would be allogeneic, potentially resulting in immune-mediated rejection. In 2007, the first human iPSCs were produced in vitro. ${ }^{33,34}$ iPSCs circumvent the aforementioned barriers to ESC use in that they are derived from adult somatic cells, allowing for autologous tissue generation without need of posttransplant immunosuppressive therapy. While the first human iPSCs were derived from adult fibroblasts, more recent advances have allowed for faster and more efficient production from ASCs, ${ }^{35}$ demonstrating further potential of MSCs in regenerative medicine.

iPSCs may overcome current limitations in wound healing therapies, but their use is not without risk. A common concern associated with cell-based therapies is that in utilizing cells with a nearly unlimited ability to self-renew and regenerate, there is the potential for malignant transformation. Reverting cells from a fully differentiated to a pluripotent state requires the use of reprogramming factors. Despite demonstrating reduced tumorigenicity over previous viral integration methods, ${ }^{36}$ alternative adenoviral, plasmid-based, and recombinant protein-based strategies ${ }^{37,38}$ continue to rely on protooncogenic reprogramming factors. ${ }^{39}$ More studies are thus needed to 
establish a safety profile for iPSC interventions. As such, there are currently no clinical trials utilizing iPSCs underway in the US. However, worldwide, their first use in a clinical trial began in 2014. While this Japanese study is aimed at treating agerelated macular degeneration, the findings from this study may hopefully assuage initial concerns allowing for further clinical study, including iPSC use in chronic wound therapy.

\section{Interactions between stem cells and chronic wounds}

\section{Chronic wound characteristics}

Physiological wound healing occurs within a microenvironment conducive to tissue repair; high levels of growth factors and mitigated degradative enzymes promote the functionality of fibroblasts, keratinocytes, and vascular endothelial cells, which are key instigators of wound healing. ${ }^{40}$ Conversely, the chronic wound bed is an environment of unabated inflammation, low mitogenic activity, excessive matrix metalloproteinases, extracellular matrix degradation, reduced angiogenesis, and premature fibroblast senescence, resulting in an overall delayed time to healing. ${ }^{41-44}$ While chronic wounds have a variety of causes such as pressure, diabetes, and peripheral arterial disease, the majority of chronic wounds share at least some of these pathological mechanisms. ${ }^{45}$ Additionally, failed reepithelialization may perpetuate these processes. ${ }^{46} \mathrm{Chronic}$ wounds demonstrate a pathological level of underhealing. The use of stem cells in addressing these lesions is geared toward restoring the wound's ability to heal, either by supplanting ineffective healing mechanisms or by augmenting muted physiological processes.

\section{Inflammation}

One of the proposed advantages of stem cell therapies is that their immunomodulatory effects can shift the wound equilibrium away from degradation toward tissue synthesis. In diabetic and venous ulcers for example, the cellular infiltrate and extracellular matrix demonstrate a lower CD4+ (T-helper)/ $\mathrm{CD}^{+}$(cytotoxic) T-cell ratio relative to acute wounds, as well as increased B-cells and plasma cells. ${ }^{47}$ This proinflammatory state can be reversed through BM-MSC suppression of T-lymphocytes ${ }^{48}$ and B-cells. ${ }^{49}$ However, the effects of chronic wounds on stem cells may impair their ability to modulate the wound microenvironment. For example, relative to acute wound fluid, chronic wound fluid is less chemotactic to ASCs and inhibits rather than stimulates their proliferation. ${ }^{50}$

\section{Infection}

The chronic inflammatory state is in part related to bacterial colonization. Interestingly, not only do MSCs decrease inflammation at the wound bed, they also enhance bacterial clearance and improve survival in sepsis via secretion of the antimicrobial peptide LL-37. ${ }^{51,52}$ However, there may be limitations to this antimicrobial effect. Long-term bacterial colonization of chronic wounds is often facilitated by polysaccharide biofilms, which may negatively impact MSCs. Exposure to biofilm-conditioned media as well as isolated soluble biofilm factors alone are both sufficient to impair MSC migration and differentiation while promoting apoptosis. ${ }^{53}$ These findings suggest that chronic wounds provide a suboptimal environment for transplanted stem cells, which may thus impede the utility of stem cell therapy in chronic wounds, at least in those with ongoing bacterial colonization with biofilm forming organisms.

\section{Hypoxia}

MSCs have a high tolerance for oxidative stress in vitro, which suggests that they are ideally suited to treating ischemic pathology, promoting tissue regeneration, and reducing reactive oxygen species burden. ${ }^{54}$ ASC survival and ensuing tissue regeneration in nonvascularized fat grafts via adipogenesis and angiogenesis suggests this phenomenon also applies in vivo. ${ }^{55}$ Additionally, MSCs may promote wound healing in response to hypoxia, increasing paracrine secretion of transforming growth factor- $\beta_{1}$, which in turn can restore fibroblast wound healing functionality inhibited under hypoxic conditions. ${ }^{56}$ Despite tolerance, and even activation of stem cells in hypoxic environments, byproducts of tissue hypoxia may be detrimental to their regenerative capabilities. As an example, elevated lactate levels, as are found in chronic wounds, are associated with gene expression in MSCs associated with inflammation and apoptosis. ${ }^{57}$

\section{Fibroblasts}

Fibroblasts are fundamental to the wound-healing cascade, but in the diabetic wound environment they display decreased proliferation and migration. ${ }^{47,58}$ However, restoration of fibroblast function is possible via paracrine signals from MSCs, such as those elucidated by Shabbir et al. ${ }^{59}$ Exosomes secreted by MSCs are taken up by fibroblasts from both normal and diabetic wounds leading to increased cellular migration, with a greater increase observed in the chronic wound fibroblasts. ${ }^{59}$

\section{Cytotoxicity}

Patients undergoing chemotherapy experience suboptimal wound healing. Paclitaxel was found to be more cytotoxic to ASCs compared to fibroblasts, ${ }^{60}$ suggesting patients 
undergoing chemotherapy may demonstrate a diminished response to stem cell-based therapies. Conversely, in an off-label trial, plerixafor was found to be better than G-CSF at mobilizing hematopoietic stem cells in diabetic patients, despite being indicated for lymphoma and multiple myeloma.${ }^{61}$ Of note, however, is that the patients in this trial were not undergoing chemotherapy for cancer treatment, and thus they do not represent the traditional patient sample receiving this drug. Radiation is another cancer-related treatment with numerous side effects, including chronic ulcer formation. Using a rat model, Huang et $\mathrm{al}^{62}$ demonstrated that ASCs have the ability to accelerate healing of these ulcers. Impairments in wound healing vary greatly across patients undergoing cancer therapy. This variability may lead to a wide variety of wound healing responses to stem cells, necessitating further study.

\section{Stem cells harvested from patients with chronic disease}

Further potential hurdles to autologous stem cell use in chronic wound therapy relate to the quality and quantity of cells harvested from patients with systemic disease. Systemic disease may be linked to depletion of angiogenic precursor cells both in the bone marrow and peripheral circulation. ${ }^{63}$ In vitro experiments by Cianfarani et $\mathrm{al}^{64}$ found ASCs isolated from diabetic mice to have lower proliferative and migration potential, muted stem cell surface marker expression, and less paracrine secretion of cytokines involved in wound healing, including vascular endothelial growth factor-A, hepatocyte growth factor, and insulin-like growth factor-1. Compared to ASCs harvested from nondiabetic mice, this also translates into a blunted improvement in diabetic wound healing. ${ }^{64}$ Human ASCs harvested from ischemic limbs of diabetic patients also display muted functionality. ${ }^{65}$ Similarly, bone marrow cells harvested from chronic wound patients and EPCs from diabetic patients demonstrate reduced growth in culture and diminished stem cell potency relative to healthy controls. ${ }^{66,67}$ In stratifying patients receiving BMMNCs for CLI based on clinical outcome, Altaner et $\mathrm{al}^{68}$ found that patients who responded to therapy have higher CD44 and CD90 MSC expression and greater interleukin-4 and interleukin-6 secretion. However, the diabetic status of the patients in this trial did not correlate with response ${ }^{68}$ which is surprising given recent studies showing diabetes impairs the ability of ASCs to promote neovascularization (via subpopulation depletion). ${ }^{69}$ Not all studies have shown that chronic systemic disease impairs stem cell functionality. Smadja et $\mathrm{al}^{70}$ noted that BM-MSCs harvested from CLI patients and healthy controls demonstrate similar proangiogenic effects when transplanted into CLI-induced mice. Increasing age and BMI are risk factors for chronic disease. Therefore, it is understandable that they also correlate negatively with stem cell yield and proliferative capacity. ${ }^{71-73}$ Overall, the effects of long-term exposure to chronic pathophysiology on endogenous stem cell properties is likely quite variable, with corresponding differences in response to autologous cell therapy between patients. It is unfortunate that the patients most in need of stem cell-based wound therapies are also the least likely to have an optimal progenitor population to draw from.

\section{Review of the clinical evidence}

To the authors' knowledge, no systematic review has been conducted that includes all types of stem cells used to manage chronic wounds. Several meta-analyses of stem cell therapies of CLI exist, but other forms of chronic wounds are omitted. Inconsistencies across clinical trials are often cited as making statistical comparisons difficult, if not impossible. Our own findings echo this sentiment, with variations between studies that include (but are not limited to) type of stem cell; method of cell harvest, purification, expansion, and administration; number of cells administered; graft immunophenotype; targeted pathophysiology; nebulous outcome measures (eg, complete wound closure vs improved wound healing vs time for given reduction in wound area); and follow-up time. We have identified 45 published trials measuring the effects of stem cell therapies on chronic wound healing, the majority of which are early Phase I trials assessing safety and efficacy, without sample randomization or placebo control. Many patients with wounds refractory to treatment over months to years may be considered to provide fairly adequate internal historical controls, though the inherent decrease in validity precludes their incorporation into meta-analysis. The difficulty of conducting randomized controlled trials has also spurred some investigators, such as Lu et al, ${ }^{20}$ to use contralateral ischemic limbs within the same patient as an internal control. Because of the overall small number of true randomized trials, these have sometimes been included in meta-analyses. This practice is likely to introduce confounding given the importance of paracrine-mediated MSC functionality. ${ }^{10}$ Given the incredible variability in trial designs that include stem cell-based wound therapy, our literature search was systematic (Figure 2, Tables S1-S3), but statistical meta-analysis was not performed. The full list of relevant studies can be found in Table 1.

The type of cell used in chronic wound therapy varies widely across clinical trials, with different degrees of overlap 


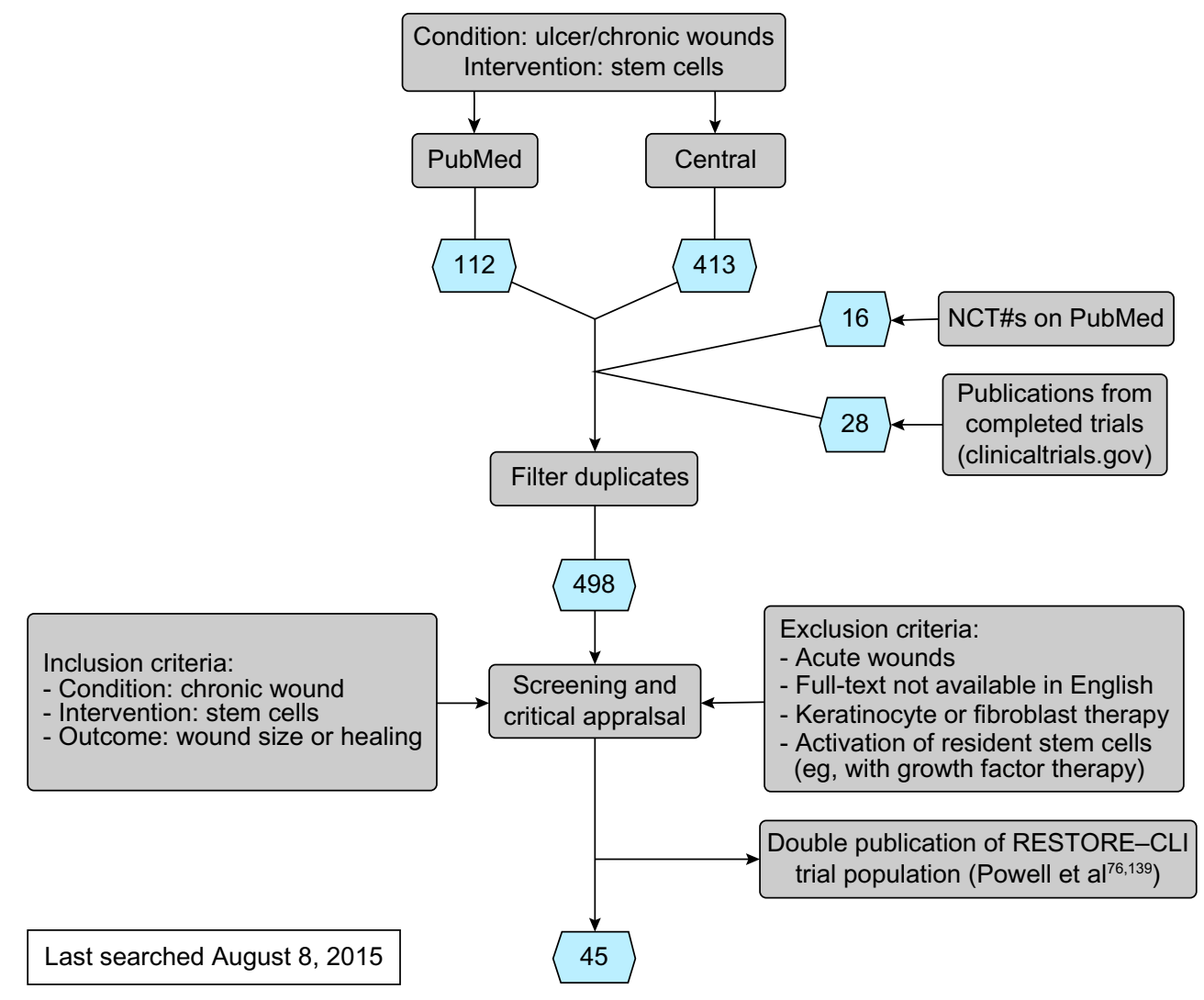

Figure 2 Literature search flowchart.

Abbreviations: NCT, National Clinical Trial; CLI, critical limb ischemia.

between them, further complicated by often-controversial classification standards. We have attempted to categorize the cell types used in the 45 trials identified as being relevant to the use of stem cells in chronic wound therapy (Figure 1, Table 1). BMMNCs are a frequently used source of progenitor cells for clinical use comprising a heterogeneous population that includes MSCs and EPCs. Numerous study protocols, including Huang et al, ${ }^{74}$ harvest cells originally localized to the bone marrow, but which have been mobilized by G-CSF into the peripheral blood (characterizing them as PBMNCs), circumventing the need for more invasive bone marrow aspiration. Within a given cell population, certain studies also include populations enriched for particular markers, such as aldehyde dehydrogenase bright cells $\left(\mathrm{ALDH}^{\mathrm{br}}\right), \mathrm{CD} 90^{+}$, or CD34+ cells. ${ }^{75-77}$ MSCs are another population frequently used in clinical trials, sourced from various tissues including bone marrow, adipose tissue, and the umbilical cord. SVF represents an additional collection of progenitor cells, including MSCs and EPCs. ${ }^{78}$

Of the 45 selected trials, only 17 include independent placebo controls ( 3 additional studies relied on internal controls) (Table 1). To date, the JUVENTAS trial is the largest published randomized controlled trials utilizing stem cells in wound healing. Results from this study indicate that there is no statistical significance between the placebo and treatment groups.$^{79}$ The fact that this study categorized major amputations as nonhealing ulcers is likely to have skewed outcomes defined as complete wound healing relative to other studies, which traditionally exclude these patients from analysis. However, the measurements of wound area reduction, which did exclude patients who underwent amputation, also demonstrated a clinically insignificant advantage of BMMNC administration.

The two largest ongoing trials, NCT01245335 and NCT02099500, predict enrollments of 200 or more each, and utilize cells from bone marrow and adipose tissue, respectively. NCT01245335 is a double-blinded, randomized, placebo-controlled trial. Though it does not specifically include wound healing as an outcome, patients must have Rutherford Category 5 peripheral artery disease to qualify for enrollment, which is defined as minor tissue loss (nonhealing ulcer, focal gangrene with diffuse pedal ischemia) ${ }^{80}$ Given that the primary outcome is improvement in Rutherford classification, this study will likely provide valid data as to the effect of bone marrow stem cells on wound healing in a much larger population than previously 


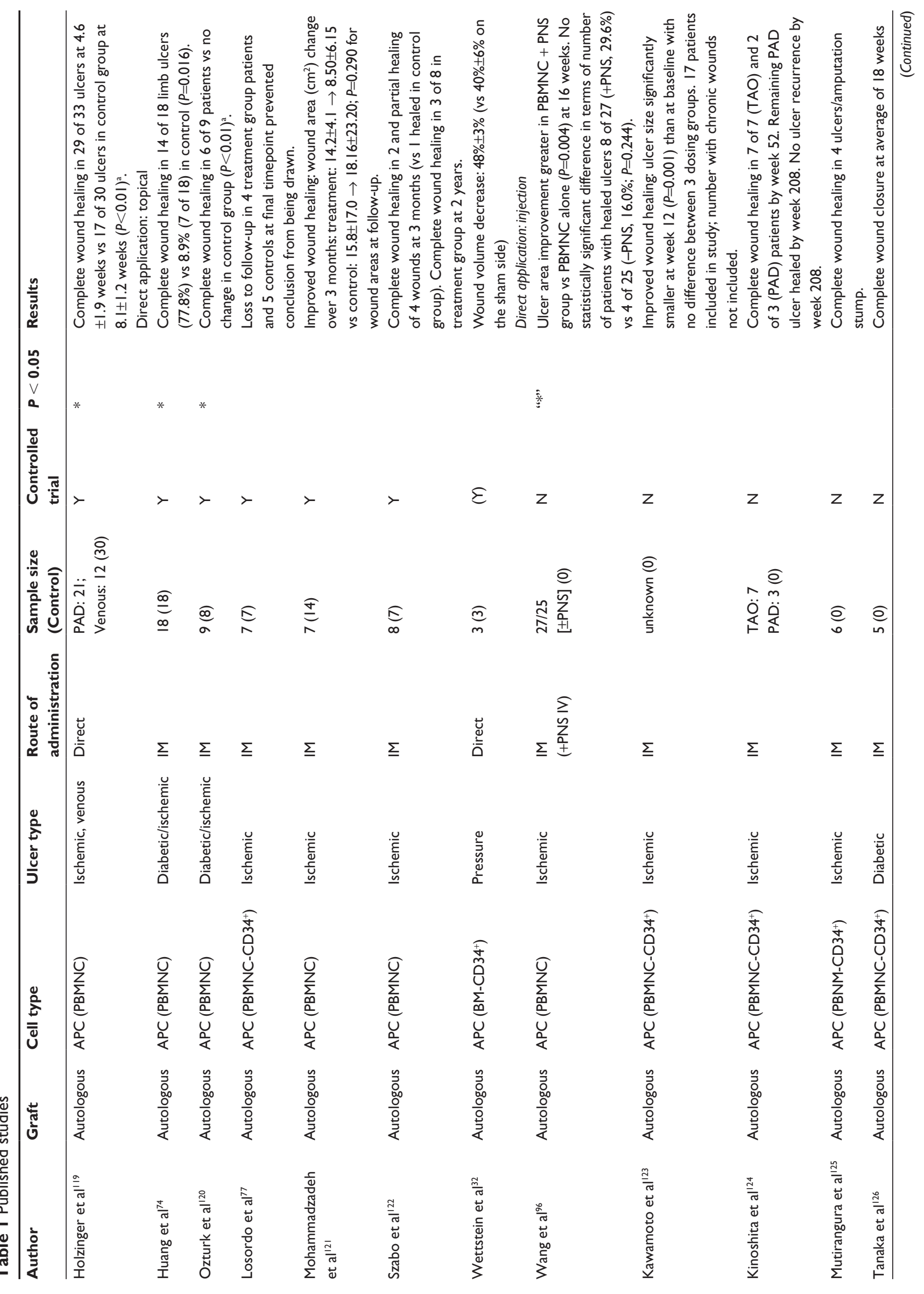




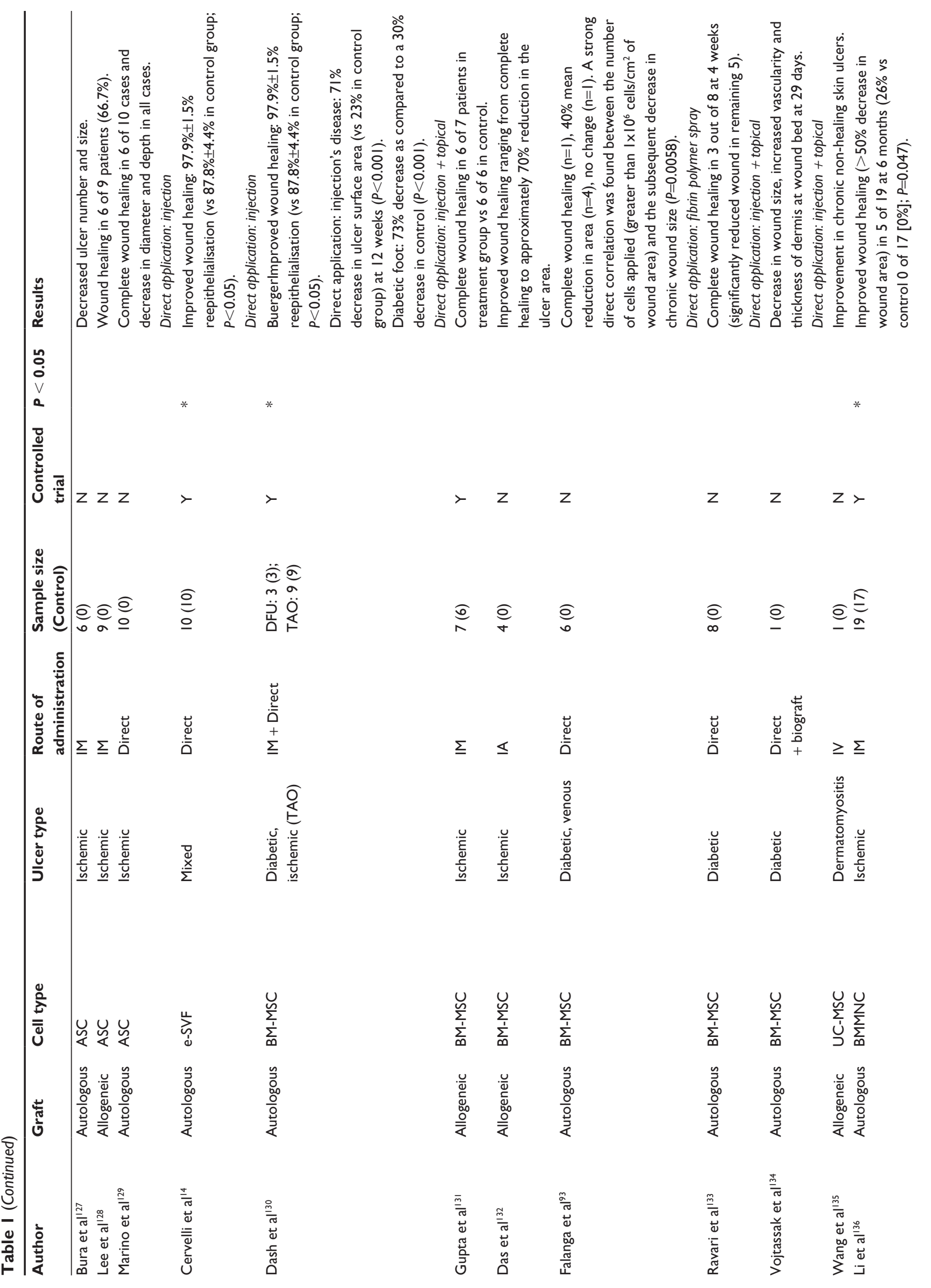



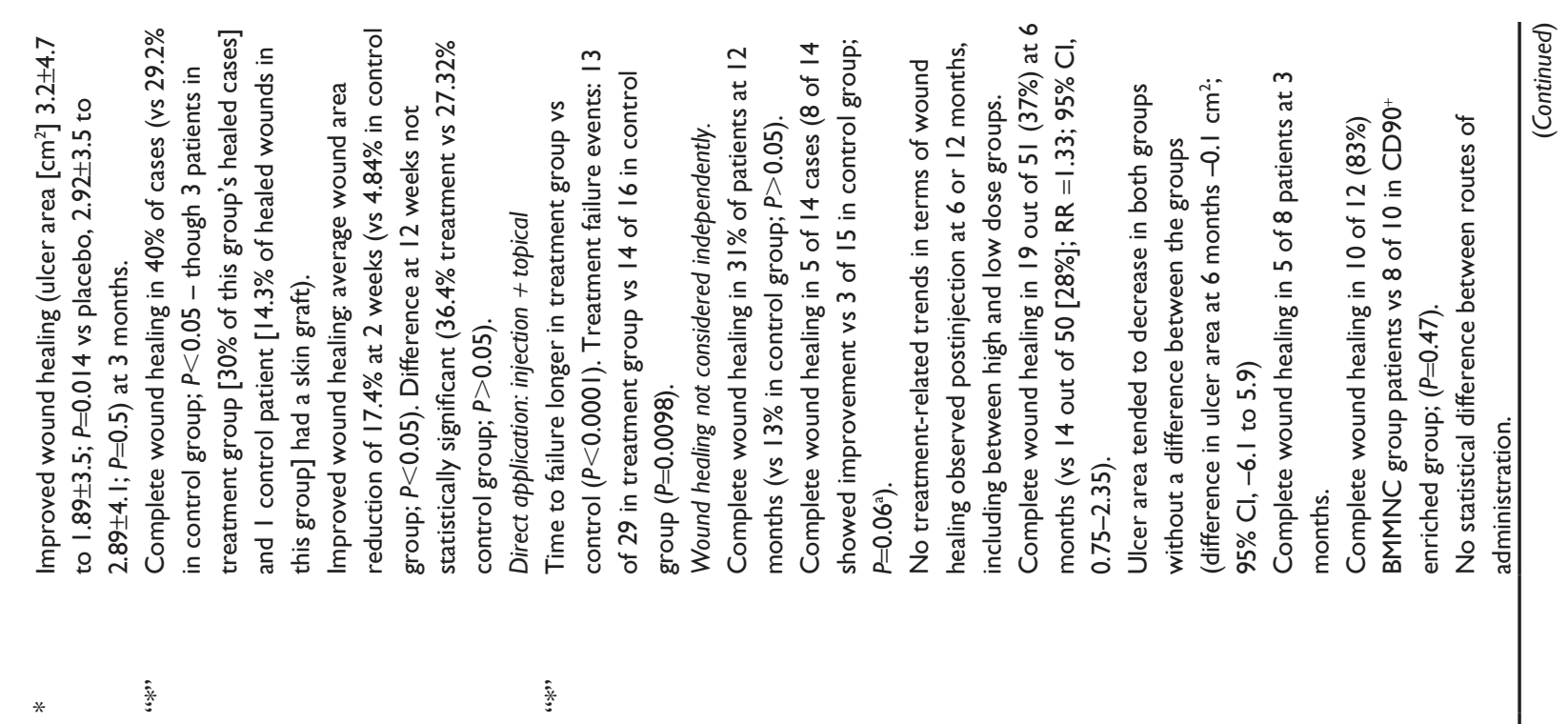

荬

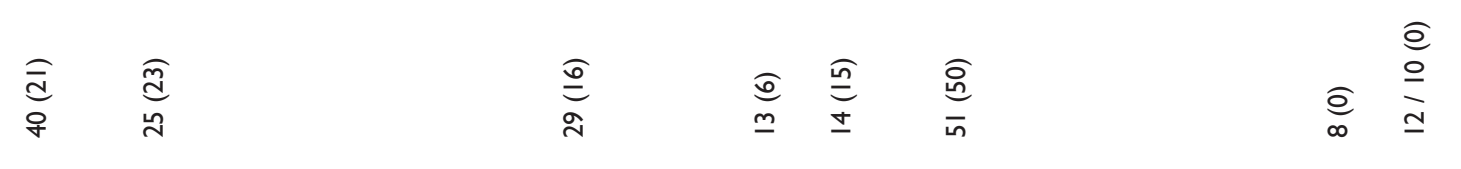

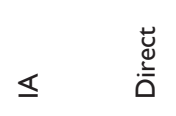

$\underline{\Sigma} \quad \underline{\Sigma} \leq$

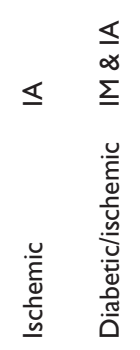

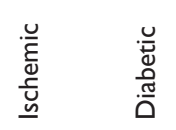

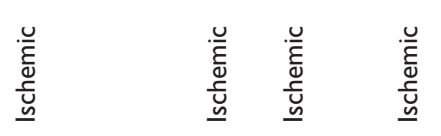

z z

$\Sigma$

$\sum_{\infty}^{U} \quad \sum_{\infty}^{U}$

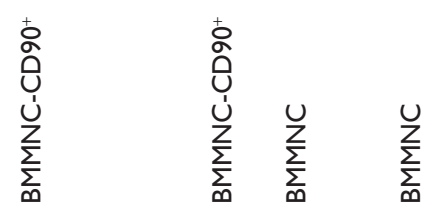

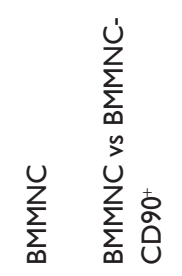

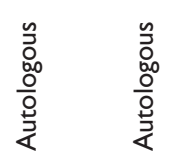

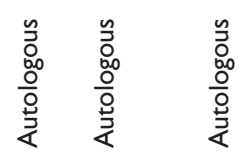

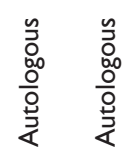

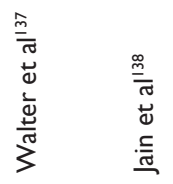

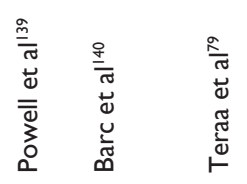

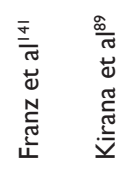




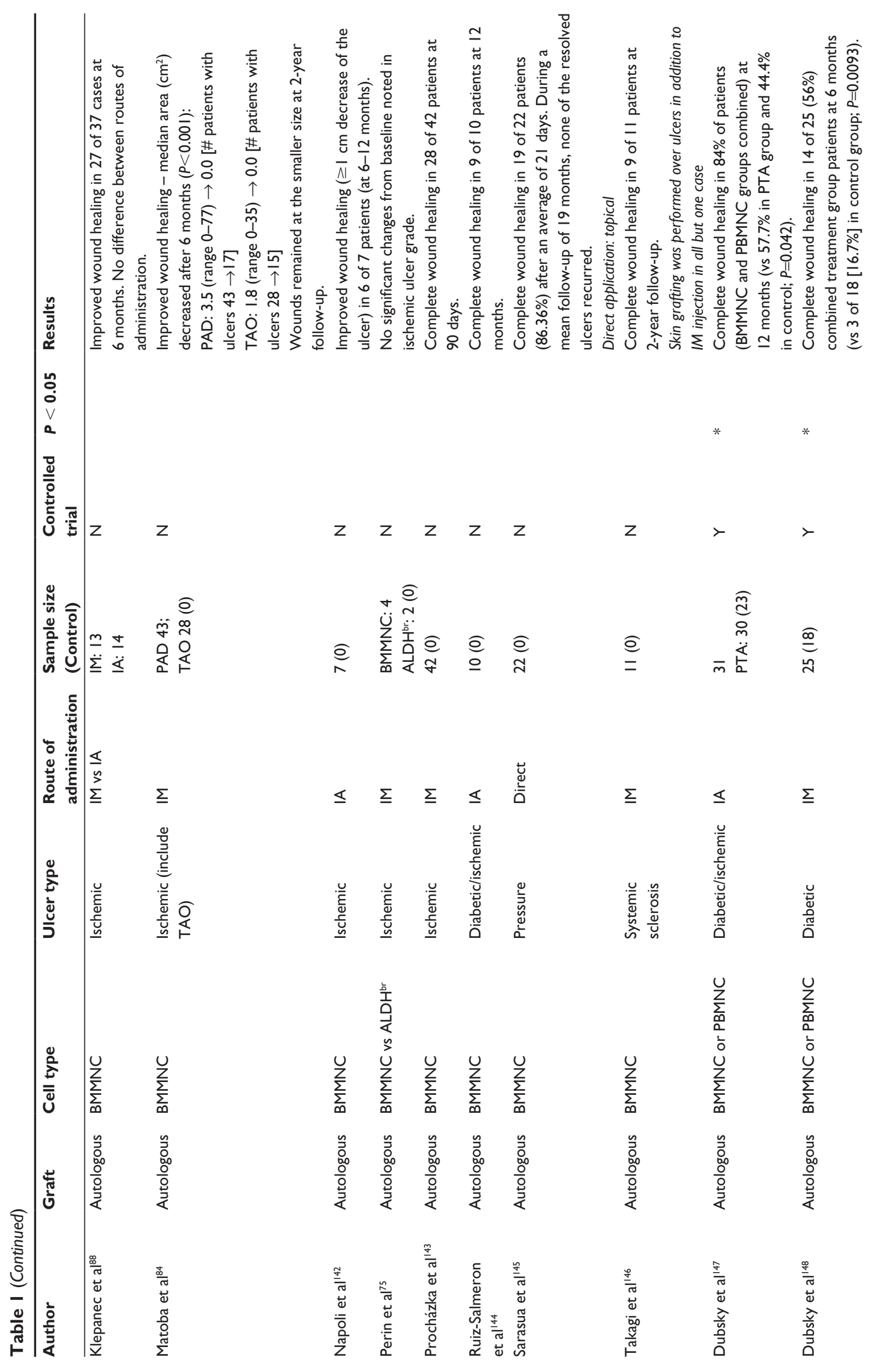




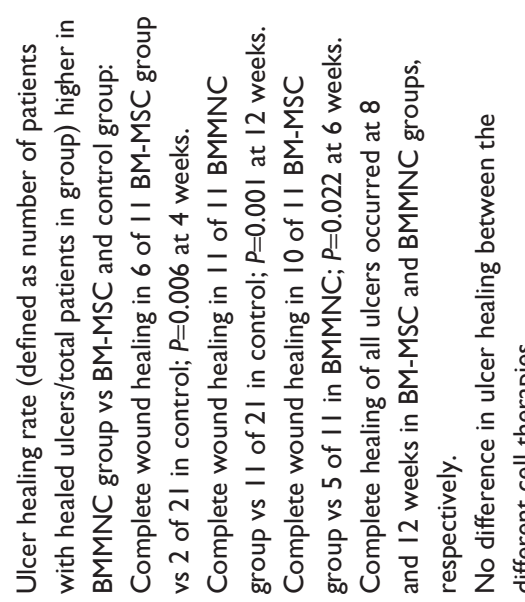

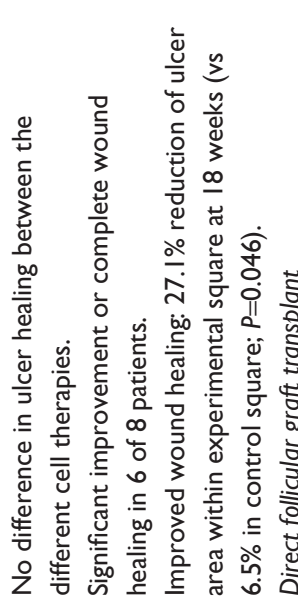

$\widetilde{乛}$

$\varepsilon$

$=$

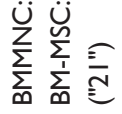

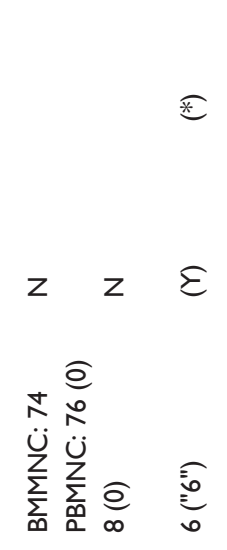

$\underline{\Sigma}$

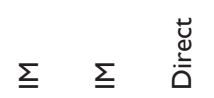

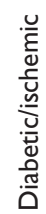

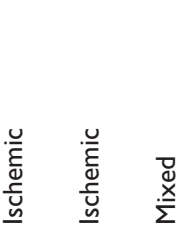

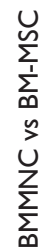

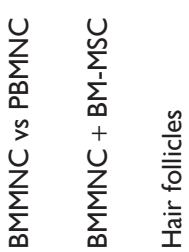

0
0
0
0
$\frac{0}{0}$
$\frac{3}{4}$

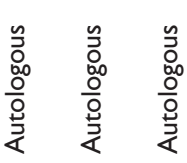

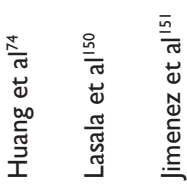

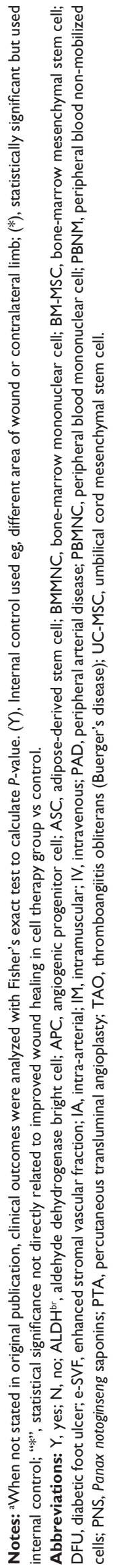


studied. While NCT02099500 addresses the relative scarcity of published clinical trials using ASCs for chronic wound therapy and includes a large sample size, this trial lacks a placebo control arm. Overall, with regard to large studies involving placebo controls, 4 of 11 ongoing trials with an enrollment $\geq 50$ do not have a placebo or sham control arms (NCT02099500, NCT01903044, NCT02089828, and NCT01456819).

Comparisons of published studies with ongoing or unpublished studies (Table 2) demonstrate a shift in focus (Figure 3). The relative increase in studies utilizing ASCs coincides with a more recent appreciation for the higher yield

Table 2 Unpublished studies

\begin{tabular}{|c|c|c|c|c|c|c|c|c|}
\hline NCT Number & Recruitment & Enrollment & Diabetes & Ischemia & Venous & Pressure & Hypertensive & Intervention \\
\hline NCTOI595776 & Completed & 8 & & $\checkmark$ & & & & $\begin{array}{l}\text { Autologous APC/ } \\
\text { PBMNC }\end{array}$ \\
\hline NCT009195I6 & Completed & 49 & & $\checkmark$ & & & & Autologous BMMNC \\
\hline NCT00883870 & Completed & 20 & & $\checkmark$ & & & & Allogeneic BM-MSC \\
\hline NCT0022II 43 & Completed & 15 & & & $\checkmark$ & & & Autologous APC \\
\hline NCT0I065337 & Completed & 30 & $\checkmark$ & $\checkmark$ & & & & Autologous BMMNC \\
\hline NCT006I6980 & Completed & 28 & & $\checkmark$ & & & & Autologous APC \\
\hline NCT0052373I & Completed & 6 & & $\checkmark$ & & & & Autologous APC \\
\hline NCT00392509 & Completed & 20 & & $\checkmark$ & & & & $\begin{array}{l}\text { Autologous BMMNC } \\
\text { vs } \mathrm{ALDH}^{\text {br }}\end{array}$ \\
\hline NCT00468000 & Completed & 86 & & $\checkmark$ & & & & $\begin{array}{l}\text { Autologous BMMNC } \\
\text { (CD } 90^{+} \text {enriched) }\end{array}$ \\
\hline NCTOI 232673 & Completed & 96 & $\checkmark$ & $\checkmark$ & & & & Autologous BMMNC \\
\hline NCT00872326 & Completed & 20 & $\checkmark$ & $\checkmark$ & & & & Autologous BMMNC \\
\hline NCT0037I37I & Completed & 160 & & $\checkmark$ & & & & Autologous BMMNC \\
\hline NCT00282646 & Completed & 40 & & $\checkmark$ & & & & Autologous BMMNC \\
\hline NCT00535548 & Completed & 3 & & & & $\checkmark$ & & Autologous APC \\
\hline NCT00677404 & Completed & 20 & & $\checkmark$ & & & & Autologous BMMNC \\
\hline NCT00797056 & Completed & 32 & & $\checkmark$ & & & & Autologous APC \\
\hline NCT0I584986 & Completed & 22 & & $\checkmark$ & & & & Autologous APC \\
\hline NCT0I4804I4 & Completed & 20 & & $\checkmark$ & & & & Autologous BMMNC \\
\hline NCT0I40838I & Completed & 38 & & $\checkmark$ & & & & Autologous BMMNC \\
\hline NCT00955669 & Completed & 40 & $\checkmark$ & $\checkmark$ & & & & $\begin{array}{l}\text { Autologous BMMNC } \\
\text { vs BM-MSC }\end{array}$ \\
\hline NCT0228783I & $\begin{array}{l}\text { Active, not } \\
\text { recruiting }\end{array}$ & 30 & $\checkmark$ & $\checkmark$ & & & & Allogeneic UC-MSC \\
\hline NCTOI 745744 & $\begin{array}{l}\text { Active, not } \\
\text { recruiting }\end{array}$ & 33 & & $\checkmark$ & & & & Autologous ASC \\
\hline NCTOI049919 & $\begin{array}{l}\text { Active, not } \\
\text { recruiting }\end{array}$ & 152 & & $\checkmark$ & & & & Autologous BMMNC \\
\hline NCT0I472289 & $\begin{array}{l}\text { Active, not } \\
\text { recruiting }\end{array}$ & 15 & & $\checkmark$ & & & & Autologous BMMNC \\
\hline NCTOI 245335 & $\begin{array}{l}\text { Active, not } \\
\text { recruiting }\end{array}$ & 210 & & $\checkmark$ & & & & Autologous BMMNC \\
\hline NCTOI75I 282 & $\begin{array}{l}\text { Active, not } \\
\text { recruiting }\end{array}$ & 66 & $\checkmark$ & $\checkmark$ & $\checkmark$ & $\checkmark$ & $\checkmark$ & $\begin{array}{l}\text { Autologous BMMNC } \\
\text { in fibrin spray }\end{array}$ \\
\hline NCTOI305863 & $\begin{array}{l}\text { Active, not } \\
\text { recruiting }\end{array}$ & 60 & & $\checkmark$ & & & & $\begin{array}{l}\text { Device: ASC coated } \\
\text { ePTFE vascular graft }\end{array}$ \\
\hline NCT02394886 & Recruiting & 5 & $\checkmark$ & $\checkmark$ & & & & Allogeneic ASC \\
\hline NCTOI484574 & Recruiting & 126 & & $\checkmark$ & & & & Allogeneic BM-MSC \\
\hline NCT0193202I & Recruiting & 10 & & & & & $\checkmark$ & $\begin{array}{l}\text { Autologous adipose } \\
\text { tissue graft }\end{array}$ \\
\hline NCT0247438I & Recruiting & 60 & $\checkmark$ & & & & & Autologous APC \\
\hline NCT0245423I & Recruiting & 38 & & $\checkmark$ & & & & $\begin{array}{l}\text { Autologous APC vs } \\
\text { BMMNC }\end{array}$ \\
\hline NCT02099500 & Recruiting & 200 & & $\checkmark$ & & & & Autologous ASC \\
\hline NCT02092870 & Recruiting & 25 & $\checkmark$ & $\checkmark$ & $\checkmark$ & $\checkmark$ & $\checkmark$ & Autologous ASC \\
\hline NCT019374I6 & Recruiting & 10 & $\checkmark$ & $\checkmark$ & & & & Autologous BMMNC \\
\hline
\end{tabular}

(Continued) 
Table 2 (Continued)

\begin{tabular}{|c|c|c|c|c|c|c|c|c|}
\hline NCT Number & Recruitment & Enrollment & Diabetes & Ischemia & Venous & Pressure & Hypertensive & Intervention \\
\hline NCT0I572376 & Recruiting & 30 & & & & $\checkmark$ & & Autologous BMMNC \\
\hline NCTOI4568I9 & Recruiting & 50 & & $\checkmark$ & & & & $\begin{array}{l}\text { Autologous BMMNC } \\
\pm \text { BM-MSC }\end{array}$ \\
\hline NCT02089828 & Recruiting & 50 & & $\checkmark$ & & & & $\begin{array}{l}\text { Autologous CD } 34^{+} \\
\text {enriched vs PBMNC }\end{array}$ \\
\hline NCT02304588 & Recruiting & 20 & $\checkmark$ & $\checkmark$ & & & & Autologous MSC \\
\hline NCT0I833585 & Recruiting & 10 & & $\checkmark$ & & & & Autologous PBMNC \\
\hline NCT02। 45897 & Recruiting & 60 & & $\checkmark$ & & & & $\begin{array}{l}\text { Autologous SVF vs } \\
\text { ASC }\end{array}$ \\
\hline NCT01916369 & Recruiting & 9 & & $\checkmark$ & & & & $\begin{array}{l}\text { CTX DP (Human } \\
\text { neural stem cell } \\
\text { product) }\end{array}$ \\
\hline NCT0I686I39 & Not yet recruiting & 10 & $\checkmark$ & $\checkmark$ & & & & Allogeneic BM-MSC \\
\hline NCTOI558908 & Not yet recruiting & 15 & & $\checkmark$ & & & & $\begin{array}{l}\text { Allogeneic } \\
\text { Endometrial-MSC }\end{array}$ \\
\hline NCTOI353937 & Not yet recruiting & 27 & $\checkmark$ & $\checkmark$ & & & & Autologous APC \\
\hline NCT02375802 & Not yet recruiting & 12 & & & & $\checkmark$ & & Autologous ASC \\
\hline NCT02477540 & Not yet recruiting & 10 & & $\checkmark$ & & & & Autologous BM-MSC \\
\hline NCT0I903044 & Not yet recruiting & 60 & & $\checkmark$ & & & & Autologous BMMNC \\
\hline
\end{tabular}

Notes: Results of clinicaltrials.gov search showing ongoing trials or unpublished studies pertaining to stem cell therapies in patients with chronic wounds, verified within the last 4 years.

Abbreviations: $\mathrm{ALDH}^{\text {br }}$, aldehyde dehydrogenase bright cell; APC, angiogenic progenitor cell; ASC, adipose-derived stem cell; BMMNC, bone-marrow mononuclear cell; BM-MSC, bone-marrow mesenchymal stem cell; SVF, enhanced stromal vascular fraction; PBMNC, peripheral blood mononuclear cell; UC-MSC, umbilical cord mesenchymal stem cell; ePTFE, expanded polytetrafluoroethylene.

\section{Published studies $n=45$}
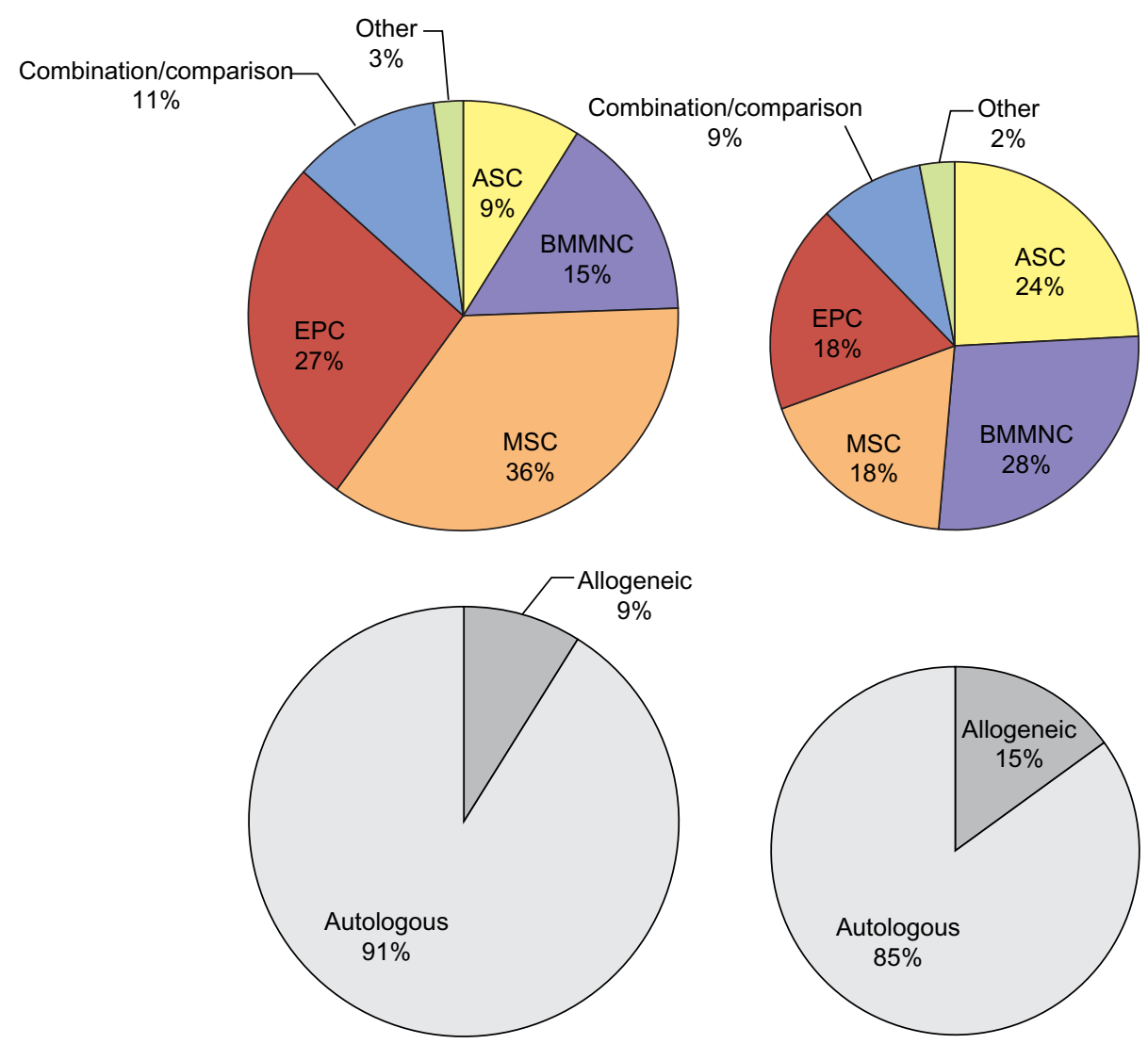

Figure 3 Relative proportions of stem cell population use in analyzed published and unpublished clinical studies.

Note: Chart area is proportional to sample size.

Abbreviations: ASC, adipose-derived stem cell; EPC, endothelial progenitor cell; MSC, mesenchymal stem cell; BMMNC, bone marrow mononuclear cell. 
of readily accessible stem cells existing within adipose tissue. Harvesting these cells from what is generally classified as biohazardous waste following liposuction may allow patients to forgo painful bone marrow aspiration. Additionally, BMMNCs appear to be favored in ongoing or unpublished trials, potentially due to several studies documenting the superiority of more heterogeneous cell transplants. ${ }^{19-21}$ The number of studies and their respective sample sizes receiving allogeneic cells is also greater among ongoing trials, reflecting an understanding that autologous stem cell potency may be blunted in patients with chronic systemic illness. Conversely, allogeneic cells have been shown to significantly enhance diabetic wound healing. ${ }^{81}$

Taken together, the published studies demonstrate that stem cell therapies can indeed lead to healing of chronic wounds resistant to traditional therapy. Meta-analyses corroborate this impression; most recently Liew et al ${ }^{82}$ calculated an odds ratio of 2.90 (95\% confidence interval [CI], 1.44-5.82) when comparing stem cell therapies with control treatment for complete ulcer healing. However, the 2015 meta-analysis by Liu et $\mathrm{al}^{83}$ suggests that this benefit may wane with longer follow-up times. While there is sufficient evidence to support the belief that stem cells improve chronic wound healing in clinical trials, the limited number of placebo control groups and inconsistent means of reporting wound healing (eg, using median wound area ${ }^{84}$ rather than complete wound closure) prevents us from establishing the true extent of this benefit. In our literature search, 9 of the 17 placebo-controlled trials showed a statistically significant improvement in wound healing with cell therapy. Interestingly, these studies include an array of methods to administer cells (intramuscular, intra-arterial, and direct application) and cell populations (PBMNCs, SVF, BM-MSCs, and BMMNCs). This suggests that many tissues and extraction methods offer means of reliably harvesting cells that can augment the healing process.

\section{Improving stem cell yield, efficacy, and lifespan - current and future techniques}

Unfortunately, though MSCs have demonstrated an ability to improve wound healing, their lifespans are short in vitro, reducing the efficacy of ex vivo expansion. Furthermore, they demonstrate suboptimal engraftment, survivability, and retention at the wound when transplanted, ${ }^{85,86}$ with several of the underlying mechanisms discussed previously. Many studies rely on intradermal or intramuscular injection to administer stem cells in suspension. Though technically simple, there is a relative loss of therapeutic efficacy, potentially caused by subsequent anoikis in the absence of cell-matrix attachment or shear forces during the injection. ${ }^{87}$ When compared, stem cells delivered intramuscularly and intra-arterially demonstrate no significant difference in terms of improved wound healing. ${ }^{88,89}$ Conversely, intravenous administration of stem cells is uncommon in chronic wound therapy because of cell entrapment in the pulmonary vasculature (the pulmonary "first-pass" effect). ${ }^{90}$ Stem cell localization to the wound bed is notably impaired in chronic (but not acute) wounds partly due to downregulated stromal cell-derived factor 1 (a chemokine attracting MSC to wound bed) secondary to uncontrolled inflammation. ${ }^{91}$ The resulting decrease of ASC migration to the wound bed further elaborates on the difficulties of systemic stem cell therapy for chronic wound healing, necessitating consideration when developing mechanisms of administration for translational medicine. Advances in stem cell surface modification offer a potential solution to this problem by targeting cells to specific tissues..$^{92}$

Poor cell engraftment and survivability are problematic considering the dose-effect relationship observed by Falanga et al, ${ }^{93}$ though the number of administered cells has not universally been shown to correlate with response. ${ }^{77}$ Defining dose in heterogeneous cell populations can also be difficult, but perhaps subpopulation composition may be less relevant (given BMMNC:MSC ratios resulted in similar clinical improvements). ${ }^{94}$ Efficacy is most likely related to a minimum required dose, ${ }^{93}$ while the lack of consensus may be related to inconsistent methodologies (eg, wound type, cell type, harvest, expansion, and administration). Increasing stem cell potency with adjuvants such as platelet-rich plasma or Panax notoginseng saponins are possible alternatives for decreasing the minimum required dose. ${ }^{95,96}$

Means of prolonging transplanted cell lifespan are now heavily sought, as MSCs must survive to influence healing. Numerous possibilities have arisen, such as hyperoxic and pan-caspase pretreatment, which reduces MSC apoptosis in ischemic microenvironments. ${ }^{97}$ Hypoxic preconditioning has also been shown to increase paracrine secretion by MSCs. ${ }^{98}$ Mohanty et $\mathrm{al}^{99}$ showed that small molecule-induced prion protein upregulation also results in increased lifespan and yield of MSCs in culture, as well as improved engraftment. Gene therapy provides further opportunity, such as protein kinase $\mathrm{G} 1 \alpha$ overexpression via adenovirus vector to promote MSC survival. ${ }^{100}$ Low-level light irradiation is another recent tool for increasing stem cell wound healing potency. ${ }^{101}$

Endogenous wound healing pathways provide further means by which to optimize MSC survival. In the presence of proapoptotic cytokines (FasL, ubiquitous in chronic 
wound microenvironments), endothelial growth factor (EGF) molecules tethered to growth scaffolds demonstrated an ability to improve MSC survival via activation of the EGFreceptor. ${ }^{102}$ Surface-tethered EGF generated a superior MSC response relative to saturating concentrations of soluble $E G F,{ }^{103}$ supporting the use of other endogenous mediators such as the matrix protein Tenascin-C combined with biosynthetic scaffolds to enhance survival of transplanted MSCs. ${ }^{104}$ Such combinations may reduce the inflammatory response to the scaffolds themselves. ${ }^{105}$

Scaffolds are valuable additions to stem cell-based wound therapy as they provide an external niche for transplanted cells outside of the hostile wound environment, while still allowing them to facilitate wound healing. In an excisional wound model, Rustad et a ${ }^{87}$ showed both a faster time to complete wound closure and a return of skin appendages in wounds treated with a biomimetic pullulan-collagen hydrogel scaffold seeded with MSCs. Moreover, this hydrogel led to longer MSC viability, increased engraftment efficiency, and enhanced angiogenesis. Clinically, Yoshikawa et al ${ }^{106}$ used a composite graft of BM-MSCs incorporated into a collagen sponge to successfully treat decubitus ulcers refractory to artificial skin grafting. ASCs embedded in silk fibroin scaffolds and fibrin gels have demonstrated a similar ability to accelerate wound healing in vivo. ${ }^{107,108}$ Autologous MSCs applied with a fibrin spray system also resulted in some improvement in patients with chronic ulcers. ${ }^{93}$ Scaffolds offer a viable means for enhancing stem cell engraftment and survivability. It is therefore likely that their incorporation into cell-based therapies will increase markedly in the near future.

Clinical implementation of cell-based therapies has opened a new frontier in the development of biomedical devices aimed at optimizing current therapies. ${ }^{109}$ The fundamental risk of contamination associated with cell products has spurred the development of closed systems for harvesting and/or culturing cells. ${ }^{110}$ Widespread clinical use also necessitates scalable technologies, such as tissue bioreactors. ${ }^{111}$ Increased automation of stem cell harvest, isolation, and expansion will allow for more standardized therapies, and subsequently more generalizable results. Novel approaches to cell population characterization such as kinome analysis may also improve clinical efficacy, or at least provide a better measure of prognosis. ${ }^{112}$

Promoting stem cell yield, survival, and efficacy at the wound bed are worthy goals. However, it is also possible that truly successful chronic wound therapy requires a deeper understanding of how the various types of stem cell therapies can modulate systemic pathophysiology. For example, in type 2 diabetes, inhibiting the local proinflammatory phenotype at the wound bed may be insufficient to completely restore wound healing; restoration of an anti-inflammatory M1/M2 macrophage equilibrium is required to allow for physiological wound healing. ${ }^{113}$

\section{Limitations}

Some of the limitations of stem cells in wound therapies have already been discussed, such as phenotypic drift in culture, heterogeneity of cell populations, and the variable quality of cells depending on their source. Beyond barriers to therapeutic efficacy, there are also potential risks, as is the case with any medical intervention. The possibility of malignant transformation exists whenever stem cells are transplanted. While this may be a greater risk with pluripotent iPSCs, study of the more commonly used multipotent MSCs has generated less of a concern. While malignant transformation has been observed in long-term culture, ${ }^{114}$ the larger body of evidence suggests that the risks of malignant transformation are low, especially prior to MSCs undergoing senescence. ${ }^{115}$ Follow-up to one of the original studies thought to demonstrate spontaneous MSC transformation has since shown a small number of malignant cells to be the culprit. ${ }^{116}$ Furthermore, the beneficial immunomodulatory properties of stem cells are also not without theoretical risks. MSC immunomodulation and homing to different target organs can increase risks of opportunistic or disseminated infections, as well as susceptibility to malignancy. ${ }^{17,118}$ Finally, transplant of biological material also carries risks of directly transmitting infectious agents. ${ }^{117}$ Overall, clinical trials demonstrate that stem cell applications to wound healing are safe, but physicians must continue to reevaluate the risks and benefits of their use as the results of more long-term follow-up studies are published.

\section{Conclusion}

Stem cells can provide the next step in advancing wound care, particularly for chronic wounds resistant to current therapies. Meta-analyses consistently show that stem cells provide a safe and effective means for promoting chronic wound healing. However, the statistically similar improvement observed in both trial arms of the large JUVENTAS study offers a solid reminder of the importance of placebo controls for measuring the true efficacy of stem cell therapy. As development of commercial devices for stem cell therapies increases, standardization of protocols will allow for greater study validity. Therapies can then be fine-tuned and catered to specific pathologies, whereas currently the different stem cell 
populations and routes of administration provide only roughly comparative results across several head-to-head studies. As we move forward, stem cells are likely to become a common tool available to clinicians for wound management, but clinical practice must follow evidence of safety and efficacy, so frequent reevaluation of the literature will be critical as new therapies are described.

\section{Disclosure}

The authors report no conflicts of interest in this work.

\section{References}

1. Tricco AC, Cogo E, Isaranuwatchai W, et al. A systematic review of cost-effectiveness analyses of complex wound interventions reveals optimal treatments for specific wound types. BMC Med. 2015;13:90.

2. Li H, Fu X. Mechanisms of action of mesenchymal stem cells in cutaneous wound repair and regeneration. Cell Tissue Res. 2012;348(3):371-377.

3. Dominici M, Le Blanc K, Mueller I, et al. Minimal criteria for defining multipotent mesenchymal stromal cells. The International Society for Cellular Therapy position statement. Cytotherapy. 2006;8(4):315-317.

4. Alvarez-Viejo M, Menendez-MenendezY, Otero-Hernandez J. CD271 as a marker to identify mesenchymal stem cells from diverse sources before culture. World J Stem Cells. 2015;7(2):470-476.

5. Ho AD, Wagner W, Franke W. Heterogeneity of mesenchymal stromal cell preparations. Cytotherapy. 2008;10(4):320-330.

6. Baer PC. Adipose-derived mesenchymal stromal/stem cells: an update on their phenotype in vivo and in vitro. World J Stem Cells. 2014;6(3):256-265.

7. Maxson S, Lopez EA, Yoo D, Danilkovitch-Miagkova A, Leroux MA. Concise review: role of mesenchymal stem cells in wound repair. Stem Cells Transl Med. 2012;1(2):142-149.

8. Gebler A, Zabel O, Seliger B. The immunomodulatory capacity of mesenchymal stem cells. Trends Mol Med. 2012;18(2):128-134.

9. Aggarwal S, Pittenger MF. Human mesenchymal stem cells modulate allogeneic immune cell responses. Blood. 2005;105(4):1815-1822.

10. Chen L, Tredget EE, Wu PY, Wu Y. Paracrine factors of mesenchymal stem cells recruit macrophages and endothelial lineage cells and enhance wound healing. PLoS One. 2008;3(4):e1886.

11. Matsumoto R, Omura T, Yoshiyama M, et al. Vascular endothelial growth factor-expressing mesenchymal stem cell transplantation for the treatment of acute myocardial infarction. Arterioscler Thromb Vasc Biol. 2005;25(6):1168-1173.

12. Jones EA, Kinsey SE, English A, et al. Isolation and characterization of bone marrow multipotential mesenchymal progenitor cells. Arthritis Rheum. 2002;46(12):3349-3360.

13. Bourin P, Bunnell BA, Casteilla L, et al. Stromal cells from the adipose tissue-derived stromal vascular fraction and culture expanded adipose tissue-derived stromal/stem cells: a joint statement of the International Federation for Adipose Therapeutics and Science (IFATS) and the International Society for Cellular Therapy (ISCT). Cytotherapy. 2013;15(6):641-648.

14. Cervelli V, Gentile P, Angelis B, et al. Application of enhanced stromal vascular fraction and fat grafting mixed with PRP in post-traumatic lower extremity ulcers. Stem Cell Res. 2011;6(2):103-111.

15. Fraser JK, Zhu M, Wulur I, Alfonso Z. Adipose-derived stem cells. Methods Mol Biol. 2008;449:59-67.

16. Durlik M, Olszewski WL. Biological effects of bone marrow in transplanted limb - a review. Ann Transplant. 2004;9(4):26-31.

17. Li WW, Talcott KE, Zhai AW, Kruger EA, Li VW. The role of therapeutic angiogenesis in tissue repair and regeneration. Adv Skin Wound Care. 2005;18(9):491-500; quiz 501-492.
18. Li S, Huang KJ, Wu JC, et al. Peripheral blood-derived mesenchymal stem cells: candidate cells responsible for healing critical-sized calvarial bone defects. Stem Cells Transl Med. 2015;4(4):359-368.

19. Rodriguez-Menocal L, Shareef S, Salgado M, Shabbir A, Van Badiavas E. Role of whole bone marrow, whole bone marrow cultured cells, and mesenchymal stem cells in chronic wound healing. Stem Cell Res Ther. 2015;6:24.

20. Lu D, Chen B, Liang Z, et al. Comparison of bone marrow mesenchymal stem cells with bone marrow-derived mononuclear cells for treatment of diabetic critical limb ischemia and foot ulcer: a double-blind, randomized, controlled trial. Diabetes Res Clin Pract. 2011;92(1):26-36.

21. Yasuhara $S$, Yasunaga $Y$, Hisatome T, et al. Efficacy of bone marrow mononuclear cells to promote bone regeneration compared with isolated CD34+ cells from the same volume of aspirate. Artif Organs. 2010;34(7):594-599.

22. Li Q, Wang Z. Influence of mesenchymal stem cells with endothelial progenitor cells in co-culture on osteogenesis and angiogenesis: an in vitro study. Arch Med Res. 2013;44(7):504-513.

23. Wu Y, Chen L, Scott PG, Tredget EE. Mesenchymal stem cells enhance wound healing through differentiation and angiogenesis. Stem Cells. 2007;25(10):2648-2659.

24. Kuo YR, Wang CT, Cheng JT, Wang FS, Chiang YC, Wang CJ. Bone marrow-derived mesenchymal stem cells enhanced diabetic wound healing through recruitment of tissue regeneration in a rat model of streptozotocin-induced diabetes. Plast Reconstr Surg. 2011;128(4):872-880.

25. Kim EK, Li G, Lee TJ, Hong JP. The effect of human adipose-derived stem cells on healing of ischemic wounds in a diabetic nude mouse model. Plast Reconstr Surg. 2011;128(2):387-394.

26. Pittenger MF, Mackay AM, Beck SC, et al. Multilineage potential of adult human mesenchymal stem cells. Science. 1999;284(5411):143-147.

27. Fathke C, Wilson L, Hutter J, et al. Contribution of bone marrowderived cells to skin: collagen deposition and wound repair. Stem Cells. 2004;22(5):812-822.

28. Akino K, Mineda T, Akita S. Early cellular changes of human mesenchymal stem cells and their interaction with other cells. Wound Repair Regen. 2005;13(4):434-440.

29. Rehman J, Traktuev D, Li J, et al. Secretion of angiogenic and antiapoptotic factors by human adipose stromal cells. Circulation. 2004;109(10):1292-1298.

30. Hu L, Zhao J, Liu J, Gong N, Chen L. Effects of adipose stem cellconditioned medium on the migration of vascular endothelial cells, fibroblasts and keratinocytes. Exp Ther Med. 2013;5(3):701-706.

31. Asahara T, Murohara T, Sullivan A, et al. Isolation of putative progenitor endothelial cells for angiogenesis. Science. 1997;275(5302): 964-967.

32. Wettstein R, Savic M, Pierer G, et al. Progenitor cell therapy for sacral pressure sore: a pilot study with a novel human chronic wound model. Stem Cell Res Ther. 2014;5(1):18

33. Takahashi K, Tanabe K, Ohnuki M, et al. Induction of pluripotent stem cells from adult human fibroblasts by defined factors. Cell. 2007;131(5):861-872.

34. Yu J, Vodyanik MA, Smuga-Otto K, et al. Induced pluripotent stem cell lines derived from human somatic cells. Science. 2007;318(5858):1917-1920.

35. Sun N, Panetta NJ, Gupta DM, et al. Feeder-free derivation of induced pluripotent stem cells from adult human adipose stem cells. Proc Natl Acad Sci U S A. 2009;106(37):15720-15725.

36. Okita K, Ichisaka T, Yamanaka S. Generation of germline-competent induced pluripotent stem cells. Nature. 2007;448(7151):313-317.

37. Zhou H, Wu S, Joo JY, et al. Generation of induced pluripotent stem cells using recombinant proteins. Cell Stem Cell. 2009;4(5):381-384.

38. Stadtfeld M, Nagaya M, Utikal J, Weir G, Hochedlinger K. Induced pluripotent stem cells generated without viral integration. Science. 2008;322(5903):945-949.

39. Liu SV. iPS cells: a more critical review. Stem Cells Dev. 2008;17(3): 391-397. 
40. Schultz GS, Davidson JM, Kirsner RS, Bornstein P, Herman IM. Dynamic reciprocity in the wound microenvironment. Wound Repair Regen. 2011;19(2):134-148.

41. Menke NB, Ward KR, Witten TM, Bonchev DG, Diegelmann RF. Impaired wound healing. Clin Dermatol. 2007;25(1):19-25.

42. Brem H, Tomic-Canic M. Cellular and molecular basis of wound healing in diabetes. J Clin Invest. 2007;117(5):1219-1222.

43. Khanna S, Biswas S, Shang Y, et al. Macrophage dysfunction impairs resolution of inflammation in the wounds of diabetic mice. PLoS One. 2010;5(3):e9539.

44. Krisp C, Jacobsen F, McKay MJ, Molloy MP, Steinstraesser L, Wolters DA. Proteome analysis reveals antiangiogenic environments in chronic wounds of diabetes mellitus type 2 patients. Proteomics. 2013;13(17):2670-2681.

45. Zelen CM, Snyder RJ, Serena TE, Li WW. The use of human amnion/ chorion membrane in the clinical setting for lower extremity repair: a review. Clin Podiatr Med Surg. 2015;32(1):135-146.

46. van Koppen CJ, Hartmann RW. Advances in the treatment of chronic wounds: a patent review. Expert Opin Ther Pat. 2015;25(8):1-7.

47. Loots MA, Lamme EN, Zeegelaar J, Mekkes JR, Bos JD, Middelkoop E. Differences in cellular infiltrate and extracellular matrix of chronic diabetic and venous ulcers versus acute wounds. J Invest Dermatol. 1998;111(5):850-857.

48. Di Nicola M, Carlo-Stella C, Magni M, et al. Human bone marrow stromal cells suppress T-lymphocyte proliferation induced by cellular or nonspecific mitogenic stimuli. Blood. 2002;99(10):3838-3843.

49. Corcione A, Benvenuto F, Ferretti E, et al. Human mesenchymal stem cells modulate B-cell functions. Blood. 2006;107(1):367-372.

50. Koenen P, Spanholtz TA, Maegele M, et al. Acute and chronic wound fluids inversely influence adipose-derived stem cell function: molecular insights into impaired wound healing. Int Wound J. 2015;12(1):10-16.

51. Mei SH, Haitsma JJ, Dos Santos CC, et al. Mesenchymal stem cells reduce inflammation while enhancing bacterial clearance and improving survival in sepsis. Am J Respir Crit Care Med. 2010;182(8):1047-1057.

52. Krasnodembskaya A, Song Y, Fang X, et al. Antibacterial effect of human mesenchymal stem cells is mediated in part from secretion of the antimicrobial peptide LL-37. Stem Cells. 2010;28(12) 2229-2238.

53. Ward CL, Sanchez CJ Jr, Pollot BE, et al. Soluble factors from biofilms of wound pathogens modulate human bone marrow-derived stromal cell differentiation, migration, angiogenesis, and cytokine secretion. $B M C$ Microbiol. 2015;15:75.

54. Valle-Prieto A, Conget PA. Human mesenchymal stem cells efficiently manage oxidative stress. Stem Cells Dev. 2010;19(12):1885-1893.

55. Eto H, Kato H, Suga H, et al. The fate of adipocytes after nonvascularized fat grafting: evidence of early death and replacement of adipocytes. Plast Reconstr Surg. 2012;129(5):1081-1092.

56. Faulknor RA, Olekson MA, Nativ NI, Ghodbane M, Gray AJ, Berthiaume F. Mesenchymal stromal cells reverse hypoxia-mediated suppression of alpha-smooth muscle actin expression in human dermal fibroblasts. Biochem Biophys Res Commun. 2015;458(1):8-13.

57. Schneider CC, Ateschrang A, Konigsrainer I, et al. Lactate influences the gene expression profile of human mesenchymal stem cells (hMSC) in a dose dependant manner. Cell Physiol Biochem. 2012;30(6):1547-1556.

58. Lerman OZ, Galiano RD, Armour M, Levine JP, Gurtner GC. Cellular dysfunction in the diabetic fibroblast: impairment in migration, vascular endothelial growth factor production, and response to hypoxia. Am J Pathol. 2003;162(1):303-312.

59. Shabbir A, Cox A, Rodriguez-Menocal L, Salgado M, Badiavas EV. Mesenchymal stem cell exosomes induce proliferation and migration of normal and chronic wound fibroblasts, and enhance angiogenesis in vitro. Stem Cells Dev. 2015;24(14):1635-1647.

60. Choron RL, Chang S, Khan S, et al. Paclitaxel impairs adipose stem cell proliferation and differentiation. J Surg Res. 2015;196(2):404-415.
61. Fadini GP, Fiala M, Cappellari R, et al. Diabetes limits stem cell mobilization following G-CSF but not plerixafor. Diabetes. 2015;64(8):2969-2977.

62. Huang SP, Huang CH, Shyu JF, et al. Promotion of wound healing using adipose-derived stem cells in radiation ulcer of a rat model. J Biomed Sci. 2013;20:51.

63. Teraa M, Sprengers RW, Westerweel PE, et al. Bone marrow alterations and lower endothelial progenitor cell numbers in critical limb ischemia patients. PLoS One. 2013;8(1):e55592.

64. Cianfarani F, Toietta G, Di Rocco G, Cesareo E, Zambruno G, Odorisio T. Diabetes impairs adipose tissue-derived stem cell function and efficiency in promoting wound healing. Wound Repair Regen. 2013;21(4):545-553.

65. Koci Z, Turnovcova K, Dubsky M, et al. Characterization of human adipose tissue-derived stromal cells isolated from diabetic patient's distal limbs with critical ischemia. Cell Biochem Funct. 2014;32(7):597-604.

66. Badiavas EV, Ford D, Liu P, et al. Long-term bone marrow culture and its clinical potential in chronic wound healing. Wound Repair Regen. 2007;15(6):856-865.

67. Tepper OM, Galiano RD, Capla JM, et al. Human endothelial progenitor cells from type II diabetics exhibit impaired proliferation, adhesion, and incorporation into vascular structures. Circulation. 2002;106(22):2781-2786

68. Altaner C, Altanerova V, Cihova M, et al. Characterization of mesenchymal stem cells of "no-options" patients with critical limb ischemia treated by autologous bone marrow mononuclear cells. PLoS One. 2013;8(9):e73722

69. Rennert RC, Sorkin M, Januszyk M, et al. Diabetes impairs the angiogenic potential of adipose-derived stem cells by selectively depleting cellular subpopulations. Stem Cell Res Ther. 2014;5(3):79.

70. Smadja DM, d'Audigier C, Guerin CL, et al. Angiogenic potential of BM MSCs derived from patients with critical leg ischemia. Bone Marrow Transplant. 2012;47(7):997-1000.

71. Zhu M, Kohan E, Bradley J, Hedrick M, Benhaim P, Zuk P. The effect of age on osteogenic, adipogenic and proliferative potential of female adipose-derived stem cells. J Tissue Eng Regen Med. 2009;3(4):290-301.

72. van Harmelen V, Skurk T, Rohrig K, et al. Effect of BMI and age on adipose tissue cellularity and differentiation capacity in women. Int $J$ Obes Relat Metab Disord. 2003;27(8):889-895.

73. Madonna R, Renna FV, Cellini C, et al. Age-dependent impairment of number and angiogenic potential of adipose tissue-derived progenitor cells. Eur J Clin Invest. 2011;41(2):126-133.

74. Huang P, Li S, Han M, Xiao Z, Yang R, Han ZC. Autologous transplantation of granulocyte colony-stimulating factor-mobilized peripheral blood mononuclear cells improves critical limb ischemia in diabetes. Diabetes Care. 2005;28(9):2155-2160.

75. Perin EC, Silva G, Gahremanpour A, et al. A randomized, controlled study of autologous therapy with bone marrow-derived aldehyde dehydrogenase bright cells in patients with critical limb ischemia. Catheter Cardiovasc Interv. 2011;78(7):1060-1067.

76. Powell RJ, Marston WA, Berceli SA, et al. Cellular therapy with Ixmyelocel-T to treat critical limb ischemia: the randomized, double-blind, placebo-controlled RESTORE-CLI trial. Mol Ther. 2012;20(6):1280-1286.

77. Losordo DW, Kibbe MR, Mendelsohn F, et al. A randomized, controlled pilot study of autologous CD34+ cell therapy for critical limb ischemia. Circ Cardiovasc Interv. 2012;5(6):821-830.

78. Yoshimura K, Shigeura T, Matsumoto D, et al. Characterization of freshly isolated and cultured cells derived from the fatty and fluid portions of liposuction aspirates. J Cell Physiol. 2006;208(1):64-76.

79. Teraa M, Sprengers RW, Schutgens RE, et al. Effect of repetitive intra-arterial infusion of bone marrow mononuclear cells in patients with no-option limb ischemia: the randomized, double-blind, placebocontrolled Rejuvenating Endothelial Progenitor Cells via Transcutaneous Intra-arterial Supplementation (JUVENTAS) trial. Circulation. 2015;131(10):851-860. 
80. Rutherford RB, Baker JD, Ernst C, et al. Recommended standards for reports dealing with lower extremity ischemia: revised version. J Vasc Surg. 1997;26(3):517-538.

81. Kuo YR, Wang CT, Cheng JT, Kao GS, Chiang YC, Wang CJ. Adiposederived stem cells accelerate diabetic wound healing through the induction of autocrine and paracrine effects. Cell Transplant. Epub April 7, 2015.

82. Liew A, Bhattacharya V, Shaw J, Stansby G. Cell therapy for critical limb ischemia: a meta-analysis of randomized controlled trials. Angiology. Epub July 19, 2015.

83. Liu Y, Xu Y, Fang F, Zhang J, Guo L, Weng Z. Therapeutic efficacy of stem cell-based therapy in peripheral arterial disease: a meta-analysis. PLoS One. 2015;10(4):e0125032.

84. Matoba S, Tatsumi T, Murohara T, et al. Long-term clinical outcome after intramuscular implantation of bone marrow mononuclear cells (Therapeutic Angiogenesis by Cell Transplantation [TACT] trial) in patients with chronic limb ischemia. Am Heart J. 2008;156(5):1010-1018.

85. Chen JS, Wong VW, Gurtner GC. Therapeutic potential of bone marrowderived mesenchymal stem cells for cutaneous wound healing. Front Immunol. 2012;3:192.

86. Nuschke A. Activity of mesenchymal stem cells in therapies for chronic skin wound healing. Organogenesis. 2014;10(1):29-37.

87. Rustad KC, Wong VW, Sorkin M, et al. Enhancement of mesenchymal stem cell angiogenic capacity and stemness by a biomimetic hydrogel scaffold. Biomaterials. 2012;33(1):80-90.

88. Klepanec A, Mistrik M, Altaner C, et al. No difference in intraarterial and intramuscular delivery of autologous bone marrow cells in patients with advanced critical limb ischemia. Cell Transplant. 2012;21(9):1909-1918.

89. Kirana S, Stratmann B, Prante C, et al. Autologous stem cell therapy in the treatment of limb ischaemia induced chronic tissue ulcers of diabetic foot patients. Int J Clin Pract. 2012;66(4):384-393.

90. Fischer UM, Harting MT, Jimenez F, et al. Pulmonary passage is a major obstacle for intravenous stem cell delivery: the pulmonary first-pass effect. Stem Cells Dev. 2008;18(5):683-692.

91. Stuermer EK, Lipenksy A, Thamm O, et al. The role of SDF-1 in homing of human adipose-derived stem cells. Wound Repair Regen. 2015;23(1):82-89.

92. Kean TJ, Lin P, Caplan AI, Dennis JE. MSCs: delivery routes and engraftment, cell-targeting strategies, and immune modulation. Stem Cells Int. 2013;2013:732742.

93. Falanga V, Iwamoto S, Chartier M, et al. Autologous bone marrowderived cultured mesenchymal stem cells delivered in a fibrin spray accelerate healing in murine and human cutaneous wounds. Tissue Eng. 2007;13(6):1299-1312.

94. Alvarez-Viejo M, Menendez-Menendez Y, Blanco-Gelaz MA, et al. Quantifying mesenchymal stem cells in the mononuclear cell fraction of bone marrow samples obtained for cell therapy. Transplant Proc. 2013;45(1):434-439.

95. Lian Z, Yin X, Li H, et al. Synergistic effect of bone marrowderived mesenchymal stem cells and platelet-rich plasma in streptozotocin-induced diabetic rats. Ann Dermatol. 2014;26(1): $1-10$.

96. Wang XC, Jiang LP, Wang XM, et al. Combination of autologous transplantation of G-CSF-mobilized peripheral blood mononuclear cells and panax notoginseng saponins in the treatment of unreconstructable critical limb ischemia. Ann Vasc Surg. 2014;28(6): 1501-1512.

97. Saini U, Gumina RJ, Wolfe B, Kuppusamy ML, Kuppusamy P, Boudoulas KD. Preconditioning mesenchymal stem cells with caspase inhibition and hyperoxia prior to hypoxia exposure increases cell proliferation. $J$ Cell Biochem. 2013;114(11):2612-2623.

98. Chang CP, Chio CC, Cheong CU, Chao CM, Cheng BC, Lin MT. Hypoxic preconditioning enhances the therapeutic potential of the secretome from cultured human mesenchymal stem cells in experimental traumatic brain injury. Clin Sci (Lond). 2013;124(3): $165-176$.
99. Mohanty ST, Cairney CJ, Chantry AD, et al. A small molecule modulator of prion protein increases human mesenchymal stem cell lifespan, ex vivo expansion, and engraftment to bone marrow in NOD/ SCID mice. Stem Cells. 2012;30(6):1134-1143.

100. Wang L, Pasha Z, Wang S, et al. Protein kinase G1 $\alpha$ overexpression increases stem cell survival and cardiac function after myocardial infarction. PLoS One. 2013;8(3):e60087.

101. Park IS, Chung PS, Ahn JC. Enhancement of ischemic wound healing by spheroid grafting of human adipose-derived stem cells treated with low-level light irradiation. PLoS One. 2015;10(6):e0122776.

102. Rodrigues M, Blair H, Stockdale L, Griffith L, Wells A. Surface tethered epidermal growth factor protects proliferating and differentiating multipotential stromal cells from FasL-induced apoptosis. Stem Cells. 2013;31(1):104-116.

103. Fan VH, Tamama K, Au A, et al. Tethered epidermal growth factor provides a survival advantage to mesenchymal stem cells. Stem Cells. 2007;25(5):1241-1251.

104. Rodrigues M, Yates CC, Nuschke A, Griffith L, Wells A. The matrikine tenascin-C protects multipotential stromal cells/mesenchymal stem cells from death cytokines such as FasL. Tissue Eng Part A. 2013;19(17-18):1972-1983.

105. Rucker M, Laschke MW, Junker D, et al. Angiogenic and inflammatory response to biodegradable scaffolds in dorsal skinfold chambers of mice. Biomaterials. 2006;27(29):5027-5038

106. Yoshikawa T, Mitsuno H, Nonaka I, et al. Wound therapy by marrow mesenchymal cell transplantation. Plast Reconstr Surg. 2008;121(3):860-877.

107. Navone SE, Pascucci L, Dossena M, et al. Decellularized silk fibroin scaffold primed with adipose mesenchymal stromal cells improves wound healing in diabetic mice. Stem Cell Res Ther. 2014;5(1):7.

108. Mendez JJ, Ghaedi M, Sivarapatna A, et al. Mesenchymal stromal cells form vascular tubes when placed in fibrin sealant and accelerate wound healing in vivo. Biomaterials. 2015;40:61-71.

109. Gimble JM, Bunnell BA, Chiu ES, Guilak F. Concise review: adiposederived stromal vascular fraction cells and stem cells: let's not get lost in translation. Stem Cells. 2011;29(5):749-754.

110. Hicok KC, Hedrick MH. Automated isolation and processing of adipose-derived stem and regenerative cells. Methods Mol Biol. 2011;702:87-105.

111. Liu N, Zang R, Yang ST, Li Y. Stem cell engineering in bioreactors for large-scale bioprocessing. Eng Life Sci. 2014;14(1):4-15.

112. Erdmann G, Suchanek M, Horn P, et al. Functional fingerprinting of human mesenchymal stem cells using high-throughput RNAi screening. Genome Med. 2015;7(1):46.

113. Gallagher KA, Joshi A, Carson WF, et al. Epigenetic changes in bone marrow progenitor cells influence the inflammatory phenotype and alter wound healing in type 2 diabetes. Diabetes. 2015;64(4): $1420-1430$.

114. Røsland GV, Svendsen A, Torsvik A, et al. Long-term cultures of bone marrow-derived human mesenchymal stem cells frequently undergo spontaneous malignant transformation. Cancer Res. 2009;69(13):5331-5339.

115. Prockop DJ, Brenner M, Fibbe WE, et al. Defining the risks of mesenchymal stromal cell therapy. Cytotherapy. 2010;12(5):576-578.

116. Garcia S, Martín MC, de la Fuente R, Cigudosa JC, Garcia-Castro J, Bernad A. Pitfalls in spontaneous in vitro transformation of human mesenchymal stem cells. Exp Cell Res. 2010;316(9):1648-1650.

117. Sundin M, Orvell C, Rasmusson I, Sundberg B, Ringden O, Le Blanc K. Mesenchymal stem cells are susceptible to human herpesviruses, but viral DNA cannot be detected in the healthy seropositive individual. Bone Marrow Transplant. 2006;37(11):1051-1059.

118. Djouad F, Plence P, Bony C, et al. Immunosuppressive effect of mesenchymal stem cells favors tumor growth in allogeneic animals. Blood. 2003;102(10):3837-3844.

119. Holzinger C, Zuckermann A, Kopp C, et al. Treatment of non-healing skin ulcers with autologous activated mononuclear cells. Eur J Vasc Surg. 1994;8(3):351-356. 
120. Ozturk A, Kucukardali Y, Tangi F, et al. Therapeutical potential of autologous peripheral blood mononuclear cell transplantation in patients with type 2 diabetic critical limb ischemia. J Diabetes Complications. 2012;26(1):29-33.

121. Mohammadzadeh L, Samedanifard SH, Keshavarzi A, et al. Therapeutic outcomes of transplanting autologous granulocyte colonystimulating factor-mobilised peripheral mononuclear cells in diabetic patients with critical limb ischaemia. Exp Clin Endocrinol Diabetes. 2013;121(1):48-53.

122. Szabo GV, Kovesd Z, Cserepes J, Daroczy J, Belkin M, Acsady G. Peripheral blood-derived autologous stem cell therapy for the treatment of patients with late-stage peripheral artery disease-results of the shortand long-term follow-up. Cytotherapy. 2013;15(10):1245-1252.

123. Kawamoto A, Katayama M, Handa N, et al. Intramuscular transplantation of G-CSF-mobilized CD34(+) cells in patients with critical limb ischemia: a phase I/IIa, multicenter, single-blinded, dose-escalation clinical trial. Stem Cells. 2009;27(11):2857-2864.

124. Kinoshita M, Fujita Y, Katayama M, et al. Long-term clinical outcome after intramuscular transplantation of granulocyte colony stimulating factor-mobilized CD34+ cells in patients with critical limb ischemia. Atherosclerosis. 2012;224(2):440-445.

125. Mutirangura P, Ruangsetakit C, Wongwanit C, et al. Enhancing limb salvage by non-mobilized peripheral blood angiogenic cell precursors therapy in patients with critical limb ischemia. J Med Assoc Thai 2009;92(3):320-327.

126. Tanaka R, Masuda H, Kato S, et al. Autologous G-CSF-mobilized peripheral blood CD34+ cell therapy for diabetic patients with chronic nonhealing ulcer. Cell Transplant. 2014;23(2):167-179.

127. Bura A, Planat-Benard V, Bourin P, et al. Phase I trial: the use of autologous cultured adipose-derived stroma/stem cells to treat patients with non-revascularizable critical limb ischemia. Cytotherapy. 2014;16(2):245-257.

128. Lee HC, An SG, Lee HW, et al. Safety and effect of adipose tissuederived stem cell implantation in patients with critical limb ischemia: a pilot study. Circ J. 2012;76(7):1750-1760.

129. Marino G, Moraci M, Armenia E, et al. Therapy with autologous adipose-derived regenerative cells for the care of chronic ulcer of lower limbs in patients with peripheral arterial disease. J Surg Res. 2013;185(1):36-44.

130. Dash NR, Dash SN, Routray P, Mohapatra S, Mohapatra PC. Targeting nonhealing ulcers of lower extremity in human through autologous bone marrow-derived mesenchymal stem cells. Rejuvenation Res. 2009;12(5):359-366.

131. Gupta PK, Chullikana A, Parakh R, et al. A double blind randomized placebo controlled phase I/II study assessing the safety and efficacy of allogeneic bone marrow derived mesenchymal stem cell in critical limb ischemia. J Transl Med. 2013;11:143.

132. Das AK, Bin Abdullah BJ, Dhillon SS, Vijanari A, Anoop CH, Gupta PK. Intra-arterial allogeneic mesenchymal stem cells for critical limb ischemia are safe and efficacious: report of a phase I study. World $J$ Surg. 2013;37(4):915-922.

133. Ravari H, Hamidi-Almadari D, Salimifar M, Bonakdaran S, Parizadeh MR, Koliakos G. Treatment of non-healing wounds with autologous bone marrow cells, platelets, fibrin glue and collagen matrix. Cytotherapy. 2011;13(6):705-711.

134. Vojtassak J, Danisovic L, Kubes M, et al. Autologous biograft and mesenchymal stem cells in treatment of the diabetic foot. Neuro Endocrinol Lett. 2006;27(Suppl 2):134-137.

135. Wang D, Zhang H, Cao M, et al. Efficacy of allogeneic mesenchymal stem cell transplantation in patients with drug-resistant polymyositis and dermatomyositis. Ann Rheum Dis. 2011;70(7):1285-1288.

136. Li M, Zhou H, Jin X, Wang M, Zhang S, Xu L. Autologous bone marrow mononuclear cells transplant in patients with critical leg ischemia: preliminary clinical results. Exp Clin Transplant. 2013;11(5):435-439.
137. Walter DH, Krankenberg H, Balzer JO, et al. Intraarterial administration of bone marrow mononuclear cells in patients with critical limb ischemia: a randomized-start, placebo-controlled pilot trial (PROVASA). Circ Cardiovasc Interv. 2011;4(1):26-37.

138. Jain P, Perakath B, Jesudason MR, Nayak S. The effect of autologous bone marrow-derived cells on healing chronic lower extremity wounds: results of a randomized controlled study. Ostomy Wound Manage. 2011;57(7):38-44.

139. Powell RJ, Comerota AJ, Berceli SA, et al. Interim analysis results from the RESTORE-CLI, a randomized, double-blind multicenter phase II trial comparing expanded autologous bone marrow-derived tissue repair cells and placebo in patients with critical limb ischemia J Vasc Surg. 2011;54(4):1032-1041.

140. Barc P, Skora J, Pupka A, et al. Bone-marrow cells in therapy of critical limb ischaemia of lower extremities - own experience. Acta Angiol. 2006;12(4):155-166

141. Franz RW, Parks A, Shah KJ, Hankins T, Hartman JF, Wright ML. Use of autologous bone marrow mononuclear cell implantation therapy as a limb salvage procedure in patients with severe peripheral arterial disease. J Vasc Surg. 2009;50(6):1378-1390.

142. Napoli C, Farzati B, Sica V, et al. Beneficial effects of autologous bone marrow cell infusion and antioxidants/L-arginine in patients with chronic critical limb ischemia. Eur J Cardiovasc Prev Rehabil. 2008;15(6):709-718

143. Procházka V, Gumulec J, Jal vka F, et al. Cell therapy, a new standard in management of chronic critical limb ischemia and foot ulcer. Cell Transplant. 2010;19(11):1413-1424.

144. Ruiz-Salmeron R, de la Cuesta-Diaz A, Constantino-Bermejo M, et al. Angiographic demonstration of neoangiogenesis after intraarterial infusion of autologous bone marrow mononuclear cells in diabetic patients with critical limb ischemia. Cell Transplant. 2011;20(10):1629-1639.

145. Sarasua JG, Lopez SP, Viejo MA, et al. Treatment of pressure ulcers with autologous bone marrow nuclear cells in patients with spinal cord injury. J Spinal Cord Med. 2011;34(3):301-307.

146. Takagi G, Miyamoto M, Tara S, et al. Therapeutic vascular angiogenesis for intractable macroangiopathy-related digital ulcer in patients with systemic sclerosis: a pilot study. Rheumatology (Oxford). 2014;53(5):854-859

147. Dubsky M, Jirkovska A, Bem R, et al. Comparison of the effect of stem cell therapy and percutaneous transluminal angioplasty on diabetic foot disease in patients with critical limb ischemia. Cytotherapy. 2014;16(12):1733-1738

148. Dubsky M, Jirkovska A, Bem R, et al. Both autologous bone marrow mononuclear cell and peripheral blood progenitor cell therapies similarly improve ischaemia in patients with diabetic foot in comparison with control treatment. Diabetes Metab Res Rev. 2013;29(5):369-376.

149. Huang PP, Yang XF, Li SZ, Wen JC, Zhang Y, Han ZC. Randomised comparison of G-CSF-mobilized peripheral blood mononuclear cells versus bone marrow-mononuclear cells for the treatment of patients with lower limb arteriosclerosis obliterans. Thromb Haemost. 2007;98(6):1335-1342.

150. Lasala GP, Silva JA, Minguell JJ. Therapeutic angiogenesis in patients with severe limb ischemia by transplantation of a combination stem cell product. J Thorac Cardiovasc Surg. 2012;144(2):377-382.

151. Jimenez F, Garde C, Poblet E, et al. A pilot clinical study of hair grafting in chronic leg ulcers. Wound Repair Regen. 2012;20(6):806-814. 


\section{Supplementary Materials}

Table SI CENTRAL search strategy

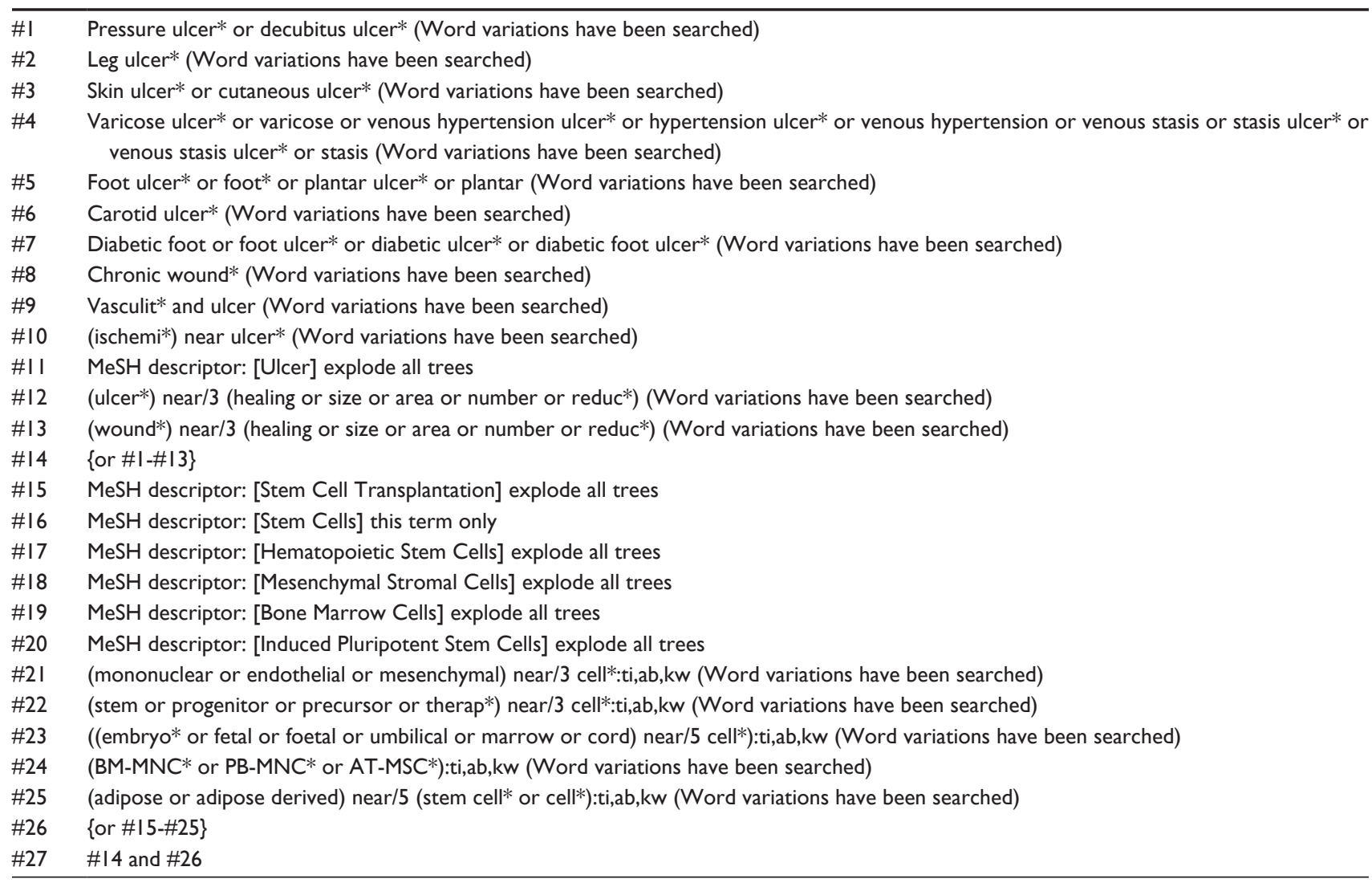

Abbreviations: BM-MNC, bone marrow mononuclear cell; PB-MNC, peripheral blood mononuclear cell; AT-MSC, adipose tissue-derived mesenchymal stem cells.

Table S2 PubMed search strategy

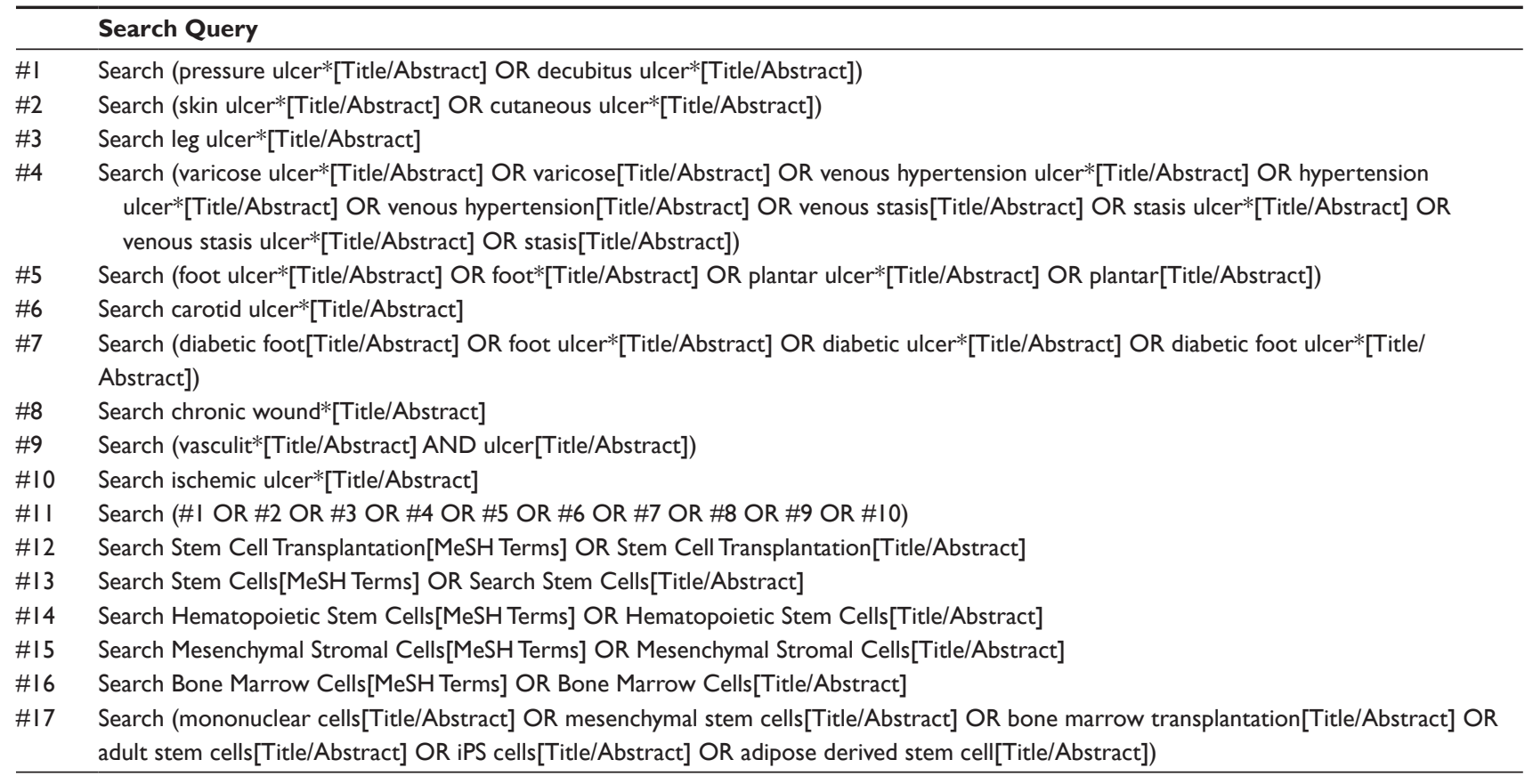


Table S2 (Continued)

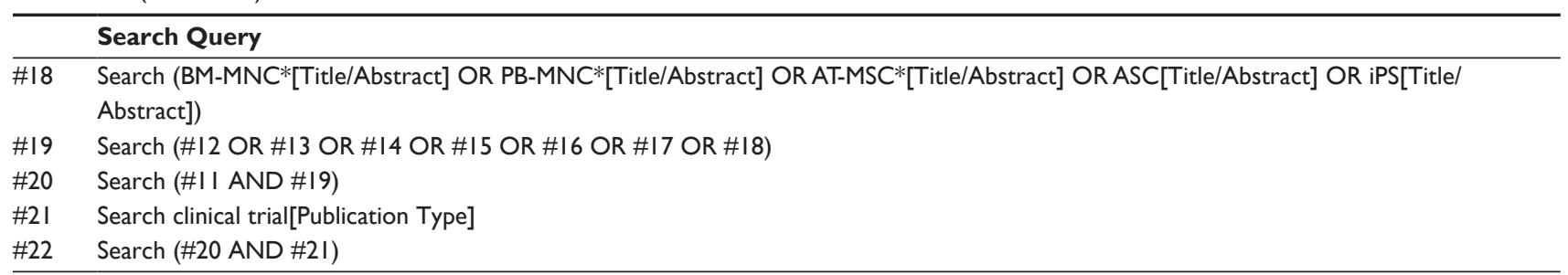

Abbreviations: iPS cells, induced pluripotent stem cells; BM-MNC, bone marrow mononuclear cell; PB-MNC, peripheral blood mononuclear cell; AT-MSC, adipose tissuederived mesenchymal stem cells; ASC, adipose-derived stem cell.

Table S3 clinicaltrials.gov search strategy

\begin{tabular}{ll}
\hline Conditions & Wound OR “Chronic wound” OR Ulcer OR Gangrene \\
& OR Ischemia OR Peripheral Vascular Diseases \\
\hline Interventions & Stem cells OR MSC OR ASC OR mononuclear OR iPS \\
Results & 697 studies found of which 48 were found to be \\
& relevant to chronic wound healing with stem cell-based \\
& therapies and verified within last 4 years (if incomplete)
\end{tabular}

Abbreviations: iPS cells, induced pluripotent stem cells; MSC, mesenchymal stem cells; ASC, adipose-derived stem cell.

\section{Publish your work in this journal}

Chronic Wound Care Management and Research is an international, peer reviewed, open access, online journal publishing original research, reviews, editorials, and commentaries on the causes and management of chronic wounds and the major issues related to chronic wound management. Topics also include chronic wounds as comorbidities to other conditions, patient adherence to therapy, and the economic burden of chronic wounds. The manuscript management system is completely online and includes a very quick and fair peer review system, which is all easy to use. Visit http://www.dovepress.com/testimonials.php to read real quotes from published authors.

Submit your manuscript here: http://www.dovepress.com/chronic-wound-care-management-and-research-journal 